\title{
Housing Decision with Divorce Risk
}

\author{
Fischer, Marcel; Khorunzhina, Natalia
}

Document Version

Accepted author manuscript

Published in:

International Economic Review

DOI:

10.1111/iere. 12385

Publication date:

2019

License

Unspecified

Citation for published version (APA):

Fischer, M., \& Khorunzhina, N. (2019). Housing Decision with Divorce Risk. International Economic Review, 60(3), 1263-1290. https://doi.org/10.1111/iere.12385

Link to publication in CBS Research Portal

\section{General rights}

Copyright and moral rights for the publications made accessible in the public portal are retained by the authors and/or other copyright owners and it is a condition of accessing publications that users recognise and abide by the legal requirements associated with these rights.

Take down policy

If you believe that this document breaches copyright please contact us (research.lib@cbs.dk) providing details, and we will remove access to the work immediately and investigate your claim. 


\title{
Housing Decision with Divorce Risk
}

Marcel Fischer and Natalia Khorunzhina

\author{
Journal article (Accepted manuscript*)
}

\section{Please cite this article as:}

Fischer, M., \& Khorunzhina, N. (2019). Housing Decision with Divorce Risk. International Economic Review, 60(3), 1263-1290. https://doi.org/10.1111/iere.12385

This is the peer reviewed version of the article, which has been published in final form at DOI: https://doi.org/10.1111/iere.12385

This article may be used for non-commercial purposes in accordance with Wiley Terms and Conditions for Self-Archiving

* This version of the article has been accepted for publication and undergone full peer review but has not been through the copyediting, typesetting, pagination and proofreading process, which may lead to differences between this version and the publisher's final version AKA Version of Record. 


\title{
Housing Decision with Divorce Risk ${ }^{*}$
}

\author{
By Marcel Fischer and Natalia Khorunzhina ${ }^{1}$ \\ University of Konstanz, Germany, and Copenhagen Business School, Denmark; \\ Copenhagen Business School, Denmark
}

\begin{abstract}
We build a life-cycle model of housing decisions under divorce risk that predicts the recent increase in divorce rates leads to reduced homeownership rates. The risk of a divorce triggers a precautionary-savings motive. However, this motive is weaker when individuals can invest in owner-occupied homes because homeowners' higher savings partially substitute for precautionary savings. When young, the larger asset accumulation due to divorcerisk induced precautionary savings enables households to buy homes earlier, whereas the presence of transaction costs leads to reduced homeownership for middle-aged and older households when divorce risk goes up.
\end{abstract}

*Manuscript received April 2016; revised November 2018

${ }^{1}$ We would like to thank Mario Crucini, Moira Daly, Marco Della Seta, James Feigenbaum, Grey Gordon, Nadia Greenhalgh-Stanley, Fane Naja Groes, Georgi Kocharkov, Weicheng Lian, David Love, Jimmy Martinez Correa, Massimo Massa, Dominik Menno, Alvaro Mezza, Robert Miller, Alvin Murphy, Andrey Pavlov, Mauricio Prado, Jesper Rangvid, Holger Sieg, Steffen Sebastian, Ramona Westermann, and seminar participants at Copenhagen Business School, the Universities of Aachen, Dortmund, Hannover, Konstanz, and Regensburg, as well as the Midwest Macro Meeting, the American Real Estate and Urban Economics Association Meeting, the Arne Ryde Workshop at Lund University, the IREBS Conference, the SGF Conference, the ECD Conference, the ReCapNet conference, the Christmas Meeting of German Economists abroad, and the German Finance Association Annual Meeting for discussions and insightful comments. We thank Dirk Krueger (the associate editor) and three anonymous referees for their comments, which helped us improve the article. Marcel Fischer gratefully acknowledges financial support from the Household Economics and Finance research initiative at Copenhagen Business

School and German Research Association (DFG), grant FI2141/1-1. All errors are our own.

This article has been accepted for publication and undergone full peer review but has not been through the copyediting, typesetting, pagination and proofreading process, which may lead to differences between this version and the Version of Record. Please cite this article as doi: $10.1111 /$ iere. 12385

This article is protected by copyright. All rights reserved. 
JEL Classification Codes: G11, D91, E21, J12, R21

Keywords: household finance, real estate, life cycle, divorce risk, family economics

Short title: Housing Decision with Divorce Risk

This article is protected by copyright. All rights reserved. 


\section{Introduction}

Since the 1970s, the share of the divorced population in the US has been on the rise, leveling off during the 1990s and remaining at a high level during the 2000s. According to the US Census Bureau, in 1970, only 6 percent of women 15 years old and over were divorced or separated, whereas by 2000, their share more than doubled, reaching 13 percent (Fields and Casper, 2001). Over the same period, homeownership rates declined for the working-age cohorts of the population (Fisher and Gervais, 2011; Goodman et al., 2015). Owner-occupied homes can be viewed as a consumption commitment that involves substantial transaction costs at trading (Chetty and Szeidl, 2007). As the risk of divorce increases, households may be reluctant to expose themselves to the prospect of an untimely sale of their marital home and shy away from homeownership. A negative correlation between homeownership and divorce rates observed in the data is suggestive of this reluctance. An owner-occupied home is the largest single financial asset for the majority of households. Nevertheless, the implications of divorce risk for housing and homeownership have received little attention in the literature. In this paper, we investigate the impact of divorce risk on housing decisions of households.

To investigate the mechanism of divorce risk on housing, we construct a life-cycle model of consumption, investment, and housing decisions, and calibrate it to micro and macro evidence. Our model shows an increase in divorce rates can explain the reduction in homeownership, observed in the data. Our model predicts that the event of a divorce leads to a long-lasting reduction in homeownership rates. The risk of divorce triggers a precautionary-savings motive and results in higher net worth, which can speed up the transition to homeownership. The precautionary-savings channel can be counteracted by the reluctance to incur sizable transaction costs associated with trading homes when the sale of the marital home is inevitable at divorce. We find that under the risk of divorce, precautionary savings enable young households to buy homes earlier, whereas the forfeiture of transaction costs upon divorce results in lower homeownership rates for middle-aged and older households.

In our model, gender, marital status, and the number and ages of children characterize the family structure of households. We distinguish between single and married households and 
allow households' marital status to change over time. During their fecund period, females can give birth to children. Homeownership is strongly desired by households with children (Öst, 2012), which our model addresses by allowing households with children to have a greater preference for living in an owner-occupied home. In the spirit of Cubeddu and Rìos-Rull (2003), marital status and fertility are treated as shocks, which are conditional on gender, age, and education. Fertility further depends on marital status, whereas divorce depends on the presence of children in the household. Mortality rates determine the transition to widowhood and out of population through death. Our comprehensive treatment of transitions in family structure is an extension to life-cycle models with housing of Cocco (2005) and Yao and Zhang (2005). Another study related to our model is Love (2010), who focuses on how family structure affects savings and asset allocation, but abstracts away from housing decisions.

Households live in an environment of uncertain formation of economic resources, such as risky returns on real estate and uninsurable income risk. As in Cocco (2005), shocks to labor income and house prices are positively correlated. Married individuals are subject to lower income volatility and are therefore less sensitive to unfavorable income shocks. Lower income risk for married households combined with its positive correlation with house-price risk makes homeownership less risky for married households and hence more attractive. ${ }^{2}$ Economies of scale enable married couples to save faster and buy homes earlier.

Our model predicts divorces decrease the demand for homeownership. This finding is consistent with the empirical analysis that we conduct using various data and different levels of aggregation from individual to aggregated regional data. In our model, the drop in homeownership is mainly driven by three effects. First, divorce instantly implies a sharp drop in household net worth due to the splitting of assets and the cost of divorce. Second, the newly divorced individual cannot take full advantage of the economies of scale. Third, the new single's income is subject to a higher volatility than the former couple's. Higher income risk for divorced households combined with its correlation with house-price risk makes homeownership riskier

\footnotetext{
${ }^{2}$ Bertocchi et al. (2011), considering marriage as a sort of safe asset, show married individuals have a higher propensity to invest in risky assets. Similarly, risky housing in our model is more attractive to married households because of the implicit spousal insurance, resulting in lower income risk.
} 
for divorced households, and hence less attractive.

Cubeddu and Rìos-Rull (2003), Fernández and Wong (2014), and Voena (2015) show higher divorce risk results in increased savings for married couples. Likewise, we find divorce risk triggers the precautionary-savings motive. When divorce risk is high, individuals save more to smooth the possible transition to a less economically favorable post-divorce state. We compare net-worth accumulation in a model with owner-occupied homes to net-worth accumulation in a model without homeownership, and we draw two conclusions. First, the dual role of owner-occupied homes as both consumption and investment goods makes investment in owner-occupied homes attractive and leads to generally higher levels of net worth than for households that cannot acquire owner-occupied homes. Second, the opportunity to invest in owner-occupied homes weakens the precautionary-savings motive, because the higher savings of homeowners substitute for precautionary savings.

Divorce risk affects homeownership through two counteracting channels. On the one hand, precautionary savings ease the transition to homeownership. On the other hand, under divorce risk, households can be reluctant to buy homes because of the loss of transaction costs upon a sale at divorce. Our model predicts divorce risk increases homeownership rates for young households, for whom the precautionary-savings effect dominates. For middle-aged and older households, we find the transaction-costs effect dominates the precautionary-savings channel. For these households, divorce risk leads to a reduction in homeownership rates.

Our paper contributes to the growing literature analyzing the rapidly changing marital structure of the population and individual financial well-being. The study of Cubeddu and Rìos-Rull (2003) is one of the early works analyzing how divorce risk affects individual savings and induces a precautionary-savings motive. González and Özcan (2013) find empirical support for increased savings followed by an easier divorce practice. The effect of divorce on female labor supply and savings is investigated in Fernández and Wong (2014), Mazzocco et al. (2014), and Voena (2015), who provide further support for the precautionary-savings motive due to divorce risk. We contribute to this literature with a novel finding about the impact of homeownership on the strength of the precautionary savings due to the risk of divorce.

The effect of higher divorce risk (evoked by a legal reform) on homeownership is investi- 
gated in the empirical study of Stevenson (2007), who focuses on newly married households. Her paper exploits differences in divorce laws across states to provide evidence that removal of fault in divorce and property settlements, that is, easier divorce coupled with proportionate financial outcomes of divorce, increases homeownership in the early years of marriage. We complement the important empirical evidence in Stevenson (2007) by disentangling the mechanism of divorce risk on homeownership in a structural model. Our model allows for a more nuanced analysis of how divorce risk affects household homeownership. To the best of our knowledge, our paper is the first to develop a model of housing decisions under divorce risk and to shed light on the complex relationship between precautionary savings, marital dissolution, and homeownership.

Fisher and Gervais (2011) focus on the effect of delayed marriage on homeownership in the presence of another background risk factor: earnings risk. In Fisher and Gervais (2011), marrying later lowers homeownership for young households, mechanically captured in their model by greater rental discount for married than for single, whereas higher earnings risk leads to a further reduction in homeownership. Our work complements theirs by showing divorces lead to lower homeownership rates. In our model, differentiated net worth and income risk, and economies of scale are factors leading to differences in homeownership rates of married and non-married. Focusing on not only the young households, as in Fisher and Gervais (2011), we find a differential effect of higher background risk, such as the risk of divorce, on homeownership for the young, middle-aged, and older households. Our findings indicate the possibility of divorce is an important risk factor, in addition to uncertainty in income and house prices - the risk factors found salient in the life-cycle literature with owner-occupied housing.

This paper proceeds as follows. Section 2 presents empirical evidence on the relationship between divorce risk and homeownership. We formulate and calibrate our life-cycle model in section 3. In section 4, we outline our model's predictions. Section 5 demonstrates the robustness of our results to various assumptions. Section 6 concludes. The appendix provides technical details on the solution of our model, the estimation of households' income process, and data construction. 


\section{Figure 1}

\section{Divorce rates}

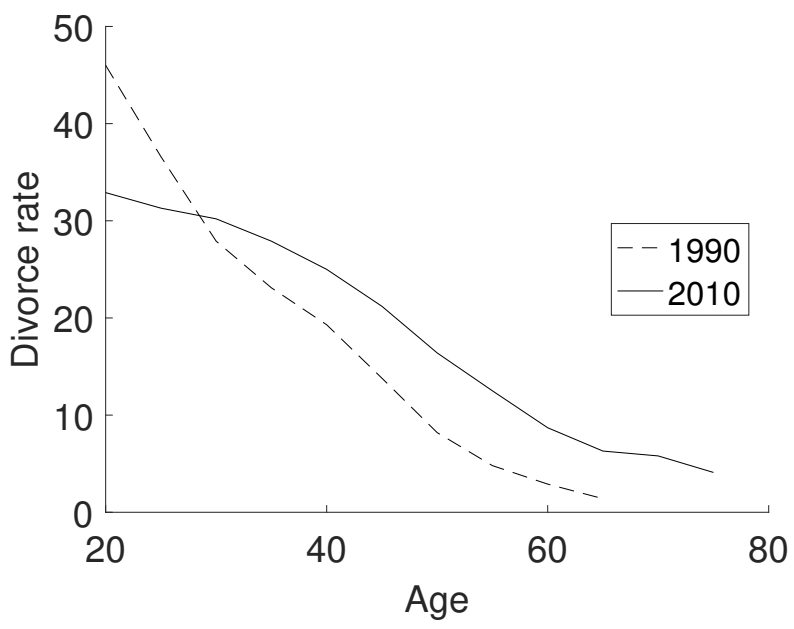

This figure depicts age-specific divorce rates per thousand married women in 1990 (dashed line) and 2010 (solid line). Divorce rates for 1990 are constructed based on the report from the Centers for Disease Control and Prevention, National Center for Health Statistics (Clarke, 1995); data from US Census Bureau, American Community Survey (Ruggles et al., 2017) are used for construction of 2010 divorce rates, following the methodology of Brown and Lin (2012).

\section{Divorce Risk and Homeownership}

In this section, we provide empirical evidence on the rise of divorce risk for the majority of US households over recent decades. Next, we show a negative correlation between homeownership and divorce rates in the data. Our empirical evidence focuses on females, because reporting the events of marital disruption is more accurate for females (Bumpass et al., 1991).

Nowadays, about one in two marriages ends in divorce. ${ }^{3}$ Although the vital statistics suggest the divorce rate for married females is declining, falling by about a quarter from its peak in 1980 by the middle of the 2000s (Kennedy and Ruggles, 2014; Stevenson and Wolfers, 2007), the reduction in the divorce rate masks a dramatic shift in the age composition of the recently divorced. Figure 1 shows that while the divorce rate per thousand married women declined between 1990 and 2010 for individuals under age 30, it increased for ages 30-35 and older,

${ }^{3}$ Only 47.8 percent (51.9 percent) of women (men) who got married between 1970 and 1973 are still not divorced after 30 years (Stevenson and Wolfers, 2011). 


\section{Figure 2}

\section{Changes in divorce rates and homeownership rates}

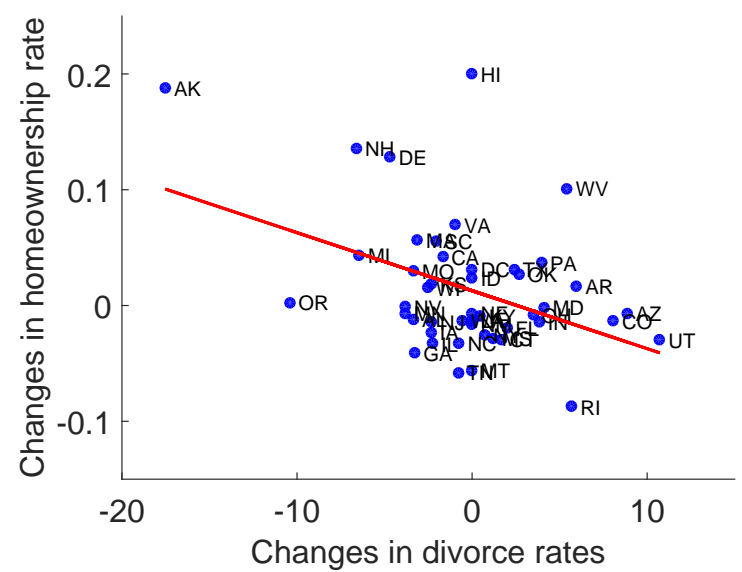

This figure depicts changes in homeownership rate and divorce rate per thousand married working-age females in the US states between 1998 and 2005, constructed from the Survey of Income and Program Participation data. The relationship is negative and statistically significant, with $R^{2}=0.17$.

exposing these cohorts of the population to a much higher risk of divorce than before. ${ }^{4}$

Over the same period, homeownership rates declined for the working-age cohorts of the population (Fisher and Gervais, 2011; Goodman et al., 2015). To explore the relationship between divorce and homeownership for the working-age population, we use the Survey of Income and Program Participation (SIPP) to construct divorce and homeownership rates on the state level. We start with the 1996 panel, when the survey was redesigned, and add monthly longitudinal observations for a full year up to 2005, restricting the data sample to the time period before the Great Recession. ${ }^{5}$ Figure 2 demonstrates the negative relationship between changes in divorce and homeownership rates for the cohort of the working-age females for US states between 1998 and 2005. Regressing annual changes in homeownership rates, measured

\footnotetext{
${ }^{4}$ The rise in divorce risk is largest among middle-aged and older adults. As Brown and Lin (2012) point out, since the 1990s, the divorce rate has doubled among adults aged 50 and older and nearly tripled for women aged $55-64$.

${ }^{5}$ Our data sample of changes in divorce rates starts in 1998, because the years 1996 and 1997 are used for tracking lagged individual marital status. The data sample also has a gap in 2000 because no full-year monthly longitudinal data can be constructed for this year.
}

This article is protected by copyright. All rights reserved. 
in percent, on annual changes in divorce rates for the working-age females in state $i$ at time $t$, we obtain

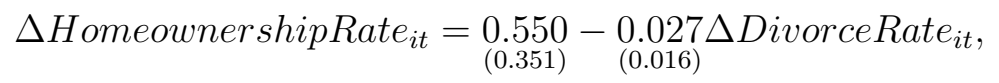

with the effect of changes in the divorce rate on changes in the homeownership rate being negative and statistically significant at the 10 percent significance level using robust standard errors. The increase in the divorce rate by one more divorce per thousand married females is associated with a reduction in the homeownership rate by about 0.03 percent. This seemingly small effect of changes in divorce rates on homeownership nevertheless has a strong cumulative effect, as is more evident from Figure 2. Our finding on the negative correlation between changes in homeownership and divorce rates is robust to sample modifications, such as including all households and extending the data up to 2010 to cover the period of the Great Recession.

\section{The Model}

In this section, we present a life-cycle model of consumption, savings, and housing, in which changes in family composition are important drivers of household decisions. We employ a discrete-time framework, in which $T$ denotes the maximum length of the household's life cycle and $t$ determines the household's adult age (computed as actual age minus 20).

Gender composition, the number and ages of children, and marital status characterize the family structure of the households. Changes in marital status and fertility are treated as shocks, which are conditional on demographic characteristics. We model marriage formation to depend on age, education, and gender. Divorce rates depend on age, gender, education, and whether children are living in the household. Age-, education-, and marital-status-dependent birth rates determine the likelihood of giving birth to a child.

Apart from uncertainty in demographic transitions, households live in an environment of uncertain formation of economic resources, including risky returns on real estate and uninsurable income risk. Households select consumption, savings, home size, and homeownership status to achieve the objective of maximizing expected lifetime utility. 


\subsection{Preferences}

Households derive utility from consumption and the home in which they live. We use a CobbDouglas per-period utility function over consumption of a nondurable good, $C_{t}$, and home size, $Q_{t}$. We allow the per-period utility to be affected by a "taste" shifter, which captures the joy and pride of having children. We model the utility shifter from children as a multiplying factor

$g \geq 1$, which increases in the number of children at a decreasing rate. The factor $g$ is higher for married individuals, reflecting a higher preference among married individuals to give birth. ${ }^{6}$

Empirical evidence in Green and White (1997) and Haurin et al. (2002) suggests growing up in an owner-occupied home positively affects childrens' outcomes because of, among other reasons, greater social capital in the neighborhood and improved school performance, which may also explain why households that plan to give birth often opt for homeownership (Öst, 2012). ${ }^{7}$ We address this empirical regularity by allowing households with children to have a greater preference for living in an owner-occupied home. Similar to Kiyotaki et al. (2011), who allow for higher utility from living in owner-occupied homes, we allow households with children to enjoy the full utility of their home only when they own it. For that purpose, we multiply the home size, $Q_{t}$, by a factor $1-\zeta \chi$, where $\zeta$ determines the welfare loss from living in a rented home with children and $\chi$ is an indicator variable that takes the value of 1 if children are living in the household and the household lives in a rented place. ${ }^{8}$ The per-period utility is given by

$$
U\left(C_{t}, Q_{t}, M_{t}, N_{t}\right)=\left(\frac{C_{t}^{1-\psi}\left((1-\zeta \chi) Q_{t}\right)^{\psi} \cdot g\left(M_{t}, N_{t}\right)}{\eta\left(M_{t}, N_{t}\right)}\right)
$$

in which $\psi$ is the housing-preference parameter, $M_{t}$ is the marital status at time $t$ (we set $M_{t}=1$ for a married individual and $M_{t}=0$ for a non-married individual), $N_{t}$ is the number

\footnotetext{
${ }^{6}$ See also Baudin et al. (2015) for the specification of preference over children with similar properties.

${ }^{7}$ See also Chetty et al. (2016) for evidence on the impact of living in better neighborhoods on children's long-term outcomes.

${ }^{8}$ Other studies that allow for higher utility from owning a home include Fisher and Gervais (2011), OrtaloMagné and Rady (1999, 2006), and Sinai and Souleles (2005).
} 
of children at time $t, \eta\left(M_{t}, N_{t}\right)$ is a function determining economies of scale adjusted for the household size, and $g\left(M_{t}, N_{t}\right)$ is a function determining the utility from having children. ${ }^{9}$

\subsection{Income and Investment}

During their working lives, households receive income modeled as a combination of a deterministic component that captures the hump shape in income over the life cycle and a random component. Our formulation of the income process closely follows Cocco et al. (2005). The growth factor for permanent income in the otherwise standard formulation of the labor-income process, such as in Carroll (1997) and Gourinchas and Parker (2002), is augmented to depend on age, gender, marital status, as well as the number and ages of children living in a household.

Labor-income volatility is typically lower for married households than for singles, because earnings fluctuations between spouses need not be perfectly correlated, thus allowing for diversification of income risk for married. Modeling income risk is important for capturing transition into homeownership. Fisher and Gervais (2011) show earnings risk helps explain a part of the homeownership dynamics. In addition, labor-income and house-price shocks are positively correlated (Cocco, 2005), which provides an important contribution to the differential impact of income volatility on homeownership for single and married households. Higher income volatility for single households combined with its high correlation with house-price shocks renders housing investments for single households riskier than for married. We assume that during work life, the growth rate of income and house prices are jointly lognormally distributed.

Upon reaching retirement age, households start receiving pension income according to their replacement ratio. The replacement ratio is defined as the initial pension income divided by final income one period before retirement and depends on the individual's gender and marital status. We follow Cocco et al. (2005) in assuming pension income is a constant fraction of final income during the retirement phase. Empirically, the replacement ratio is below 1, creating an incentive to build up savings during working life to avoid a sizable consumption drop at retirement age. Retirement thus is an important factor driving individuals' savings behavior

\footnotetext{
${ }^{9}$ Given that $M_{t}$ and $N_{t}$ are discrete variables, changes in family composition are events that induce discontinuous jumps in the utility function.
} 
and their net worth. Net worth in turn affects the ability to acquire homeownership. In our model, households can save in a risk-free bond and buy owner-occupied homes.

\subsection{Rents, Maintenance, and Moving Costs}

The consumption of housing services is associated with recurring expenses for both owners and renters. Renters periodically pay rental costs, $\delta^{r} Q H$, with $\delta^{r}$ denoting the rate of rental costs, $Q$ the size of the home measured in number of housing units, and $H$ the price per housing unit. To offset depreciation of their homes, owners incur maintenance costs, $\delta^{m} Q H$, where $\delta^{m}$ is the rate of maintenance costs. The rate of running housing costs, $\delta$, can thus be expressed as

$$
\delta\left(I_{t}\right)=\delta^{r}\left(1-I_{t}\right)+\delta^{m} I_{t}
$$

in which $I_{t}$ is an indicator variable that takes the value of 1 if the household owns the home during period $t$, and 0 if the household rents it.

Non-recurring costs occur when households move to owner-occupied homes. As in Bajari et al. (2013), Fischer and Stamos (2013), and Van Hemert (2010), a household acquiring a new home faces a transaction cost of $\tau Q_{t} H_{t}$, in which $Q_{t}$ is the size of the new home. Transaction costs are also incurred if the household continues to be a homeowner but changes home size. Overall, non-recurring transaction cost, $\tau^{t}$, can be summarized as follows:

$$
\tau^{t}\left(Q_{t}, Q_{t-1}, I_{t}, I_{t-1}, H_{t}\right)=Q_{t} H_{t} \begin{cases}\tau \quad \text { if home purchase }\left(I_{t}-I_{t-1}=1\right) \\ \tau \quad \text { if owner changes home size }\left(I_{t}=I_{t-1}=1, Q_{t} \neq Q_{t-1}\right) \\ 0 \quad \text { otherwise. }\end{cases}
$$

Transaction costs are an important element for determining when and how often households buy owner-occupied homes. Size adjustments of an owner-occupied home are costly and should therefore only be made on an infrequent basis, thus leading to a long-term commitment to housing of a fixed size (Chetty and Szeidl, 2007). In addition, at divorce, households face an untimely sale of their marital home and the loss of transaction costs for trading it. 


\subsection{Family Structure}

Throughout their lives, households can experience changes in marital status and can give birth. We model the probability of marriage to depend exogenously on age, education, and gender. Marriage has a tendency to be increasingly assortative along age, education, net worth, and income (Bredermeier and Juessen, 2013; Fernández and Wong, 2014; Greenwood et al., 2014; Schwartz and Mare, 2005). Following this evidence, we assume males and females marry a person of the opposite gender, but the same age, and with the same education, income, and net-worth level. ${ }^{10}$ An advantage of this assumption is that it keeps the optimization problem numerically tractable. We demonstrate the robustness of our results to this assumption in section 5, in which we allow individuals to marry a partner with different age, education, income, or net worth.

We construct fertility rates to depend on age, education, and marital status. Accounting for children is important for our paper because households' savings strategies and births of children are related (Choi, 2017), and household savings are an important driver of households' ability to acquire homeownership. The effect of children on homeownership in our model is captured through a penalty term from renting when children are present in a household (see equation (2)). Higher utility from living in owner-occupied homes helps generate the demand for homeownership among single and divorced households with children, who generally have lower household net worth but a strong incentive to pursue homeownership for family reasons. Further, the number of children is an important determinant of a divorced mother's transfer income because of child-support payments, which depend on the number and ages of children.

Our way of modeling births of children closely follows Love (2010) and has the desirable feature of keeping the optimization problem numerically tractable. We make four assumptions. First, we assume mothers beyond the age of 40 do not give birth. ${ }^{11}$ Second, children born before the mother turns 30 are referred to as being born "early," whereas others are referred

\footnotetext{
${ }^{10}$ Similar assumptions have been made in the related literature. Marriage is modeled assortatively over age in Cubeddu and Rìos-Rull (2003), along the income dimension in Love (2010), and over asset holdings in Voena (2015).

${ }^{11}$ Empirically, less than 1 percent of females beyond age 40 give birth to a child (Mathews and Ventura, 1997).
} 


\section{Figure 3}

\section{Divorce rates by age, gender, and children}
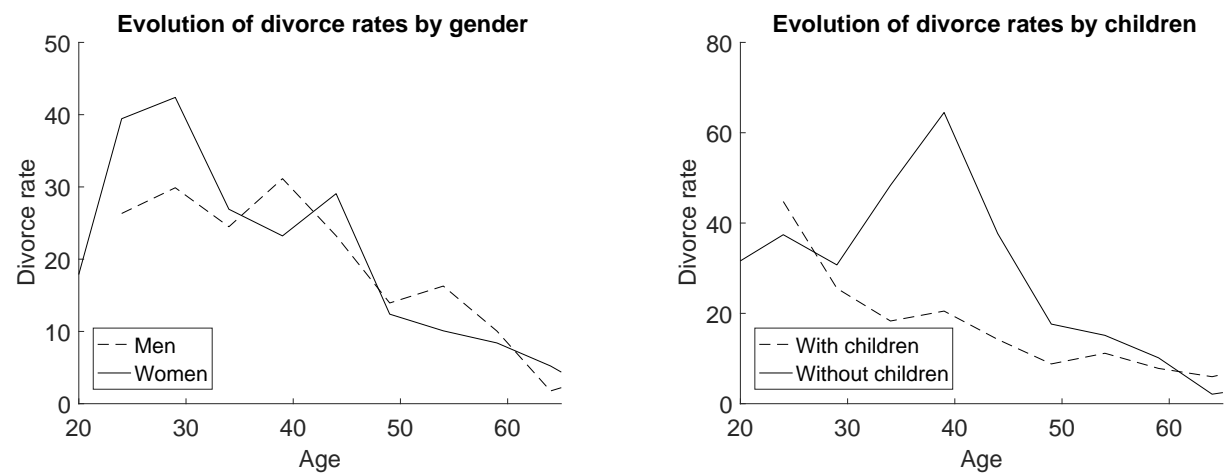

This figure depicts age-specific divorce rates per thousand married individuals by age. The left panel reports values conditional on gender; the right panel presents values conditional on whether children are living in the household. Data source: SIPP 2001, Topical Module 2.

to as being born "late." We assume females do not give birth to more than four children in either of these two periods. Therefore, the maximum number of children born to a female is eight. Third, we assume children born within each of these two periods are evenly spaced two years apart. Finally, the number of children and whether the first child was born early or late determine the age of the mother when the first child was born. ${ }^{12}$ The mother has the first child in the early period at 27 if only one child is born in that period, at 26 if two are born, at 25 if three are born, and at 24 if four are born. For children born late, the mother is 34 if one child is born, 33 if two are born, 32 if three are born, and 31 if four are born. Children live in a household until they turn 18 . From ages 18 to 22 , children attend post-secondary school. ${ }^{13}$

Divorce rates depend on age, gender, education, and whether children are living in the household. ${ }^{14}$ Computing detailed divorce rates requires high-quality micro-level data, particu-

\footnotetext{
${ }^{12}$ These last two assumptions significantly reduce the number of state variables required to solve the life-cycle consumption, housing, investment, and family problem, and thereby make solving the model possible. Essentially, they imply the mother's age and whether a child was born "early" or "late" determine the age of the children.

${ }^{13}$ As Love (2010) points out, this assumption is consistent with most parents' expectations.

${ }^{14}$ For college graduates, Farnham et al. (2011) find divorces are also affected by past house-price changes. In particular, when house prices fall, homeowners can get locked into their homes, which makes trading the home and getting divorced very costly. For high school graduates, on whom our work focuses, these authors find no
} 
larly to capture the impact of children on divorce rates. We use 2001 SIPP data combined with its topical module on marital histories to compute divorce rates, and refer to the 2001 rates as our base-case divorce rates throughout.

In Figure 3, we depict how divorce rates from the 2001 SIPP data vary with age, gender (left panel), and whether children are living in the household (right panel). Divorce rates are generally declining with age. From the left panel, divorce rates are relatively similar for males and females, except for the young individuals before 30, when divorce rates are higher for females. Divorce rates for households with children are substantially lower than for households without children - especially at those ages when households are most likely to have children living at home.

Although divorce is, strictly speaking, not an exogenous event, life-cycle models with detailed family structure often treat changes in marital status, and divorces in particular, as exogenous. For example, Cubeddu and Rìos-Rull (2003), Love (2010), and Fernández and Wong (2014) assume exogenous marital changes. Given the intertwined nature of the familycomposition decisions with resource-accumulation choices, a proper way to treat a family process in a life-cycle model is to let it arise endogenously from a model (e.g., Greenwood et al., 2016; Guner and Knowles, 2007; Mazzocco et al., 2014; Santos and Weiss, 2012; Voena, 2015). Both approaches, however, lead to similar conclusions about the response of savings to divorce risk, especially for females, who prefer to increase savings. Following divorce, a household faces a reduction in savings, whereas a greater divorce risk strengthens the precautionarysavings motive. In view of the similar conclusions, our choice of modeling divorces as a shock rather than a choice gives us the advantage of keeping our model numerically tractable. An issue with an exogenous divorce may arise around the time of the divorce shock. Unanticipated timing of the divorce may lead to over-reaction to divorce in the short run. As Mazzocco et al. (2014) show, individuals tend to smooth their resource allocation in anticipation of divorce, whereas in our model, the immediate response of individuals to a divorce shock may be sharper. However, the long-term effects of divorce, which our work is concerned with, are not likely to be altered.

significant effects. 
We assume that at the moment of divorce, household income, assets, and liabilities are split equally. We allow for a 10 percent deduction to account for legal costs and inefficiencies resulting from the splitting of assets. Mazzocco et al. (2014) document that just-divorced individuals on average have a little less than half of household wealth before the divorce, providing empirical support for an equal split after accounting for divorce cost as a reasonable way to deal with the allocation of wealth in the event of a divorce. ${ }^{15}$

Likewise, we assume that at the moment of divorce, an owner-occupied home is sold and proceeds are also divided equally. For states with equal property division, Davis (1983) reports that in many cases in which a home is a marital asset subject to division, it is sold rather than awarded intact. Even the presence of children does not increase the likelihood that the wife, who typically is the custodial parent, is awarded the marital home at divorce. Davis (1983) further documents that under the equitable-division scheme, the court-ordered sale and division of a marital home is less than half the rate recorded for equal-division states. Many women who are awarded the family home are forced to sell it to meet financial obligations. Overall, because the home is often the couple's largest asset, it can seldom be balanced by other property awards, which makes awarding the marital home outright to one ex-spouse difficult to implement - even in the case of equitable division. ${ }^{16}$

In our model, the assumption that the owner-occupied home is sold after a divorce and

\footnotetext{
${ }^{15}$ The overwhelming majority of US states have enacted equal or equitable distribution of marital property at divorce (Davis, 1983; Gray, 1998). Equal division means awarding equivalent shares of marital property to ex-spouses, whereas equitable distribution allows for judicial discretion, especially for the cases in which children are involved.

${ }^{16}$ Turner (2006) points out that when the outright award of the marital home is not possible, the court has several options. The first option is to order the home sold and proceeds shared. The second option is to award the home to one spouse, subject to a monetary transfer to the other spouse. Often, spouses in need of a marital home, such as those with custody of children, are the least likely to have sufficient income to pay a monetary award, which makes a sale of the home inevitable. The third option is to give the right to use the marital home to one spouse for a period of time after the divorce, whereas the other spouse's interest is represented by imposing a lien upon the home. After a period of exclusive use terminates, the home is normally sold and the proceeds are divided. All three options end with the home being sold, although under the third option, it may take a while until the sale occurs.
}

This article is protected by copyright. All rights reserved. 
household income is split is mainly made for simplicity and can be relaxed. Our conclusions do not differ from the case in which we model the home as going to the custodial parent. A family-size home is typically too large, expensive, and costly to maintain for a divorced individual; therefore, in our model, selling a home in the event of a divorce is optimal. ${ }^{17}$

We assume children stay with their mothers, whereas fathers pay child support. After divorce, the growth rate of the income process is - until a possible remarriage - determined by the income process of a single. This transition effectively assumes the past marital status inflicts no long-lasting effect on the evolution of income, unlike contemporaneous marital status, an individual's age, and the presence and the ages of children.

\subsection{The Optimization Problem}

The household maximizes expected lifetime utility by deciding each period, $t=0,1, \ldots, T$, upon consumption of the non-durable good, $C_{t}$; home size, $Q_{t}$; ownership status, $I_{t}$; and the fraction of household wealth invested into bonds, $\pi_{t}^{b}$. Whereas single individuals maximize their own utilities, married individuals agree to maximize the sum of their equally weighted utilities. ${ }^{18}$ That is, as long as they are married, they care as much about their partner's wellbeing as they care about their own.

Hurd (1989) shows households' incentives for bequests are small. We therefore abstract away from bequests to children when the last household member dies. A household's evolution

\footnotetext{
${ }^{17}$ The study of Stevenson (2007) finds that homeownership of newlyweds is affected by how assets are divided in the event of a divorce. Newlyweds are more likely to become homeowners in states where easier divorce practice is coupled with equal or equitable division of marital assets and less likely in the states with common law division of assets. Our model is able to match her empirical results that, under easier divorce, homeownership increases when marital property is split equally and decreases when marital property is divided far from equally. The results are available upon request.

${ }^{18} \mathrm{We}$ also explored settings in which we let the female (male) individual make the decisions when married, that is, in which the female (male) individual utility is maximized. Making the decisions based on the female's preferences under marriage leads to slightly later homeownership and slightly lower homeownership after divorce, whereas savings are not much affected. Letting the male individual decide during marriage leads to minor changes in the female's evolution of homeownership and savings over the life cycle.
} 
of net worth, $W_{t}$, is given by

$$
W_{t}=\pi_{t-1}^{b} W_{t-1} R+L_{t}+H_{t} \cdot Q_{t-1} \cdot I_{t-1}+\Delta W_{t}^{M D},
$$

in which $L_{t}$ is the household's income received from time $t-1$ to $t, R=1+r$ is the gross return on the bond, and $\Delta W_{t}^{M D}$ denotes a change in household net worth due to marriage or divorce at time $t$. In the event of a marriage, $\Delta W_{t}^{M D}$ corresponds to the new partner's wealth. In the event of a divorce, household net worth is split equally after accounting for the 10 percent cost of splitting the assets. That is, at divorce, the new single household loses 55 percent of net worth and $\Delta W_{t}^{M D}=-0.55\left(\pi_{t-1}^{b} W_{t-1} R+L_{t}+H_{t} Q_{t-1} I_{t-1}\right)$. When the marital status does not change, $\Delta W_{t}^{M D}=0$. The household's budget constraint is

$$
W_{t}=C_{t}+\delta\left(I_{t}\right) \cdot H_{t} \cdot Q_{t}+H_{t} \cdot Q_{t} \cdot I_{t}+\tau^{t}\left(Q_{t}, Q_{t-1}, I_{t}, I_{t-1}, H_{t}\right)+W_{t}^{S}+\Xi_{t}
$$

in which $W_{t}^{S}$ denotes child support paid or received at time $t$, and $\Xi_{t}$ is total college costs paid at time $t$. We impose the restriction that bonds can only be shorted to finance homeownership. The minimum housing downpayment for homeowners is $\kappa>0$, implying the amount of debt, $-\pi_{t}^{b} W_{t}$, has to obey

$$
-\pi_{t}^{b} W_{t} \leq(1-\kappa) I_{t} \cdot H_{t} \cdot Q_{t}
$$

in every period. Ideally, we would only require this constraint to hold when a home is purchased. However, this condition increases the number of state variables required to solve our optimization problem and would thus significantly increase its complexity. We follow the literature (e.g., Yao and Zhang, 2005) and impose the constraint to hold in every period. To avoid being forced to sell their homes when house prices fall, households typically do not lever up to the maximum possible level.

We use recursive preferences (Epstein and Zin, 1989), which allows for disentangling the relationship between the degree of risk aversion, $\gamma$, and the elasticity of intertemporal substitution, $\phi$. Relaxing the relationship between risk aversion and the elasticity of intertemporal 
substitution is important for matching the evolution of homeownership and household net worth simultaneously. ${ }^{19}$ Hence, an individual's optimization problem is given by

$$
\begin{aligned}
& V\left(X_{t}, Y, t\right)=\sup _{\left\{C_{t}, Q_{t}, I_{t}, \pi_{t}^{b}\right\}}\left[(1-\beta) \cdot U\left(C_{t}, Q_{t}, I_{t}, M_{t}, N_{t}^{e}, N_{t}^{l}\right)^{1-\frac{1}{\phi}}\right. \\
& +\beta \cdot \mathbb{E}\left[M _ { t } \left\{f_{t} \tilde{f}_{t}\left(\frac{1}{2} V\left(X_{t+1}, Y, t+1\right)^{1-\gamma}+\frac{1}{2} V\left(X_{t+1}, \tilde{Y}, t+1\right)^{1-\gamma}\right)\right.\right. \\
& \left.+f_{t}\left(1-\tilde{f}_{t}\right) V\left(X_{t+1}, Y, t+1\right)^{1-\gamma}+\left(1-f_{t}\right) \tilde{f}_{t} V\left(X_{t+1}, \tilde{Y}, t+1\right)^{1-\gamma}\right\} \\
& \left.\left.+\left(1-M_{t}\right) f_{t} V\left(X_{t+1}, Y, t+1\right)^{1-\gamma}\right]^{\frac{1-\frac{1}{\phi}}{1-\gamma}}\right]^{\frac{1}{1-\frac{1}{\phi}}},
\end{aligned}
$$

subject to equations (3) to (7), in which $f_{t}$ is the probability of the individual surviving from time $t$ to $t+1, \tilde{f}_{t}$ is the corresponding probability of a partner, $Y$ is the individual's gender, $\tilde{Y}$ is a partner's gender, $N_{t}^{e}$ and $N_{t}^{l}$ are the number of children born "early" and "late," respectively, and

$$
X_{t}=\left[Q_{t-1}, I_{t-1}, L_{t}, W_{t}, H_{t}, M_{t}, N_{t}^{e}, N_{t}^{l}, t\right]
$$

is the vector of state variables. We solve this life-cycle consumption, investment, and housing problem numerically. The technical details are outlined in Appendix A.

\subsection{Parameterization}

In this section, we describe the parameterization of the model. We estimate the evolution of real home prices, using the log-returns on the Case Shiller Home Price Index from 1953 to

\footnotetext{
${ }^{19}$ The related papers of Cubeddu and Rìos-Rull (2003) and Fisher and Gervais (2011) focus on matching either homeownership rates (Fisher and Gervais, 2011) or savings (Cubeddu and Rìos-Rull, 2003). In these papers, it may be sufficient to work with CRRA preferences and control for the risk-aversion, $\gamma$, and the elasticity of intertemporal substitution via one parameter only. In our work, we want to match both the evolution of homeownership rates and net worth over the life cycle. Controlling for risk aversion, $\gamma$, and the elasticity of intertemporal substitution independently (specifically choosing the elasticity of intertemporal substitution higher than $1 / \gamma$ ) allows for a better fit of homeownership rates and net worth over the life cycle.
} 
2013. ${ }^{20}$ The expected historical annual real house-price return does not differ statistically from zero. We therefore set the expected annual real house-price return to 0.0 percent. That is, homeowners are not rewarded as much for risk by a high housing risk premium as they are by saved rent payments. The historical annual real volatility of the home-price index is 5.5 percent. However, price changes for individual homes are far from perfectly correlated. The aggregation in the house-price index reduces house-price volatility. Case and Shiller (1989) argue the annual volatility of individual house prices is close to 15 percent. Bourassa et al. (2009) find empirical estimates of a similar magnitude. We therefore set house-price volatility to 15 percent. The risk-free rate is set to 1.9 percent, the average real one-year Treasury Bill rate from 1953 to 2013.

Correlation between house-price and income shocks is set to $\rho_{H L}=0.55$, the empirical estimate of Cocco (2005). The home-equity requirement is 20 percent; the rent rate, maintenance costs, and the costs of trading an owner-occupied home are set to 6.0 percent, 1.5 percent, and 6.0 percent, respectively, which are the values used in Yao and Zhang (2005).

We estimate the income processes separately for single males, single females, and married households, using the 1980-2011 waves of the Panel Study of Income Dynamics (PSID) for high school graduates with observed income, on whom we focus throughout our work. Our estimation closely follows Cocco et al. (2005) and Love (2010) and is outlined in more detail in Appendix B. The resulting coefficients reported in Table 1 are of a similar order of magnitude as those estimated by Love (2010), yet reflect that our coefficients are estimated using the PSID data until 2011, thus also covering the recent financial crisis. According to our results in Table 1, a married household's income is estimated to be less volatile than that of singles, consistent with the diversification of income risk stressed by Santos and Weiss $(2012,2016)$.

At age 20, individuals are single and have no children. We set the initial level of net worth to US\$25,000, the median level of net worth right after receipt of income for a 20-year-old individual in the PSID data. ${ }^{21}$ We set the retirement age to 65 , and the maximum household

\footnotetext{
${ }^{20}$ This home-price index is publicly available on Robert Shiller's homepage: http: //www. econ. yale. edu/ shiller/data.htm.

${ }^{21}$ We include income in net worth, because we measure net worth in our model right after the receipt of one-year income. In the SIPP data, the median level of net worth right after receipt of income for a 20 -year
} 
Table 1

Income process

\begin{tabular}{|c|c|c|c|}
\hline Description & Male & Female & Married \\
\hline \multicolumn{4}{|l|}{ Fitted age polynomials } \\
\hline Constant & -1.5606 & -0.7839 & -0.8939 \\
\hline Age & 0.1202 & 0.0601 & 0.0628 \\
\hline $\mathrm{Age}^{2} / 100$ & -0.2030 & -0.0544 & -0.0324 \\
\hline $\mathrm{Age}^{3} / 10,000$ & 0.0948 & -0.0091 & -0.0430 \\
\hline Replacement rate & 0.9537 & 0.9460 & 0.9478 \\
\hline \multicolumn{4}{|l|}{ Coefficient estimates } \\
\hline \multirow[t]{2}{*}{ Children age $0-1$} & -0.0624 & -0.0141 & -0.0233 \\
\hline & $(0.1196)$ & $(0.0277)$ & $(0.0073)$ \\
\hline \multirow[t]{2}{*}{ Children age 2-4 } & 0.0608 & -0.0072 & -0.0267 \\
\hline & $(0.0801)$ & $(0.0199)$ & $(0.0061)$ \\
\hline \multirow[t]{2}{*}{ Children age 5-7 } & 0.0343 & 0.0171 & -0.0198 \\
\hline & $(0.0582)$ & $(0.0187)$ & $(0.0062)$ \\
\hline \multirow[t]{2}{*}{ Children age 8-10 } & 0.0300 & 0.0432 & -0.0075 \\
\hline & $(0.0501)$ & $(0.0188)$ & $(0.0065)$ \\
\hline \multirow[t]{2}{*}{ Children age $11-12$} & -0.0452 & 0.0751 & 0.0140 \\
\hline & $(0.0524)$ & $(0.0208)$ & $(0.0082)$ \\
\hline \multirow[t]{2}{*}{ Children age $13-15$} & 0.0189 & 0.0864 & -0.0087 \\
\hline & $(0.0463)$ & $(0.0185)$ & $(0.0075)$ \\
\hline \multirow[t]{2}{*}{ Children age 16-18 } & -0.0004 & 0.0965 & 0.0086 \\
\hline & $(0.0587)$ & $(0.0236)$ & $(0.0099)$ \\
\hline \multirow[t]{2}{*}{ Constant } & 9.6390 & 9.3115 & 10.0419 \\
\hline & $(0.0518)$ & $(0.0461)$ & $(0.0356)$ \\
\hline$N$ & 5,321 & 7,526 & 27,273 \\
\hline$R$-squared & 0.0721 & 0.0921 & 0.1101 \\
\hline \multirow[t]{2}{*}{ Variance permanent shock } & 0.0203 & 0.0113 & 0.0111 \\
\hline & $(0.0035)$ & $(0.0015)$ & $(0.0010)$ \\
\hline
\end{tabular}

This table summarizes the estimated coefficients for the income process of single males, single females, and married couples, using the 1980-2011 waves of the PSID for households whose head has a high school diploma. Results are based on fixed-effects regressions described in detail in Appendix B. Standard errors are reported in parentheses.

age to 95 . We take mortality rates from the 2007 Period Life Table published by the US Social old individual is about US\$18,000. Given that our individuals have Epsein-Zin preferences, the exact initial level of net worth does not affect their consumption shares, homeownership decisions, housing-to-networth ratios, mortgage-to-networth ratios, and family decisions.

This article is protected by copyright. All rights reserved. 
Security Administration.

We construct birth rates as in Love (2010), using fertility data published in a US National Center for Health Statistics report (Mathews and Ventura, 1997, Table 5, page 13). The report publishes birth rates by race, education, and marital status for different age brackets. Fertility rates for ages 20 through 40 are estimated by fitting a third-degree polynomial (evaluated at the median age in each bracket) through the reported probabilities. The utility shifter from children, $g\left(M_{t}, N_{t}\right)$, is calibrated to match the empirically observed average number of children per household with children. We compute average age-, education-, and sex-dependent marriage rates using the SIPP data. For male and female individuals aged $20-90$ observed in the SIPP data, we estimate the probability of divorce conditional on educational attainment and on whether individuals have children, by fitting a third-degree polynomial through the probabilities evaluated at the median age in five-year brackets. ${ }^{22}$

For the payment of child support and college costs, we follow the modeling of Love (2010). We model child support by adopting the income-sharing formulas prevalent in most US states. For children under 18, the noncustodial parent pays a constant share of income: 17 percent for one child, 25 percent for two children, 29 percent for three children, 31 percent for four children, and 33 percent for five or more children. In case of a divorce, children typically stay with their mothers. We therefore assume the noncustodial parent is male, and focus our analysis on females. For children from 18 to 22, parents cover college expenses, modeled as a fraction of household income. Following the empirical estimates of Turly and Desmond (2011), we assume married couples spend 9 percent of income per year on each child's college eduction, whereas single parents spend 7 percent.

The function $\eta$ characterizes economies of scale adjusted by household size and is formulated as $\eta\left(M_{t}, N_{t}\right)=\left(1+M_{t}+0.7 N_{t}\right)^{0.7}$, in which $M_{t}$ is the marital status and $N_{t}$ is the number of children living in the household during period $t .^{23}$ The five parameters, elasticity

\footnotetext{
${ }^{22}$ For individuals beyond the age of 90 , we set divorce rates to zero due to the lack of data. At very high ages, divorce rates are close to zero and the share of individuals still having a partner at the age of 90 is very low.

${ }^{23}$ This equivalence-scale formulation, recommended by Citro and Michael (1995), is, among others, also used in the related studies of Scholz et al. (2006) and Love (2010).
} 
Table 2

\section{Base-case parameter values}

\begin{tabular}{lccc}
\hline Description & Parameter & Value & Source \\
\hline Degree of risk aversion & $\gamma$ & 3 & Own calibration \\
EIS & $\phi$ & 0.5 & Own calibration \\
Housing preference & $\psi$ & 0.2 & Own calibration \\
Utility discount factor & $\beta$ & 0.963 & Own calibration \\
Max. length of investment horizon & $T$ & 75 & Own choice \\
Risk-free rate (percent) & $r$ & 1.9 & Own estimation \\
Expected housing return (percent) & $\mu_{H}$ & 0.0 & Own estimation \\
Volatility housing return (percent) & $\sigma_{H}$ & 15 & Case and Shiller (1989) \\
Correlation between housing and income (percent) & $\rho_{H L}$ & 55 & Cocco (2005) \\
Minimum housing downpayment (percent) & $\kappa$ & 20 & Yao and Zhang (2005) \\
Renting-costs rate (percent) & $\delta^{r}$ & 6.0 & Yao and Zhang (2005) \\
Rate of maintenance costs (percent) & $\delta^{m}$ & 1.5 & Yao and Zhang (2005) \\
Home purchasing costs (percent) & $\tau$ & 6.0 & Yao and Zhang (2005) \\
Penalty children renters (percent) & $\zeta$ & 15 & Own calibration
\end{tabular}

of intertemporal substitution, $\phi$, the housing preference, $\psi$, the penalty term, $\zeta$, the degree of risk-aversion $\gamma$, and the time-preference parameter, $\beta$, are determined internally in the model to match the evolution of net worth and the homeownership rate over the life cycle. We find that $\psi=0.2, \phi=0.5, \gamma=3, \beta=0.963, \zeta$ at 15 percent, jointly provide a good fit. Our value for the housing-preference parameter, $\psi$, corresponds to the choice of Yao and Zhang (2005) and Marekwica et al. (2013). Our penalty term, $\zeta$, is in the range of the empirical estimates between 0.13 and 0.23 in Haurin et al. (2002). The value of the EIS, the degree of risk aversion, and the time-preference parameter are in the range of values typically considered in the literature.

\section{Household Decisions}

In this section, we illustrate the impact of divorce risk on housing decisions. All model predictions reported throughout are based on 10,000 simulations of the optimal paths conditional on the individual's survival. To account for potential pre-existing homeownership and net worth, the initial distribution of the income-to-net-worth ratio, the homeownership status, and the housing-to-net-worth ratio at age 20 are drawn from the joint empirical distribution in the PSID data. 


\section{Figure 4}

\section{Evolution of homeownership rate over the life cycle}

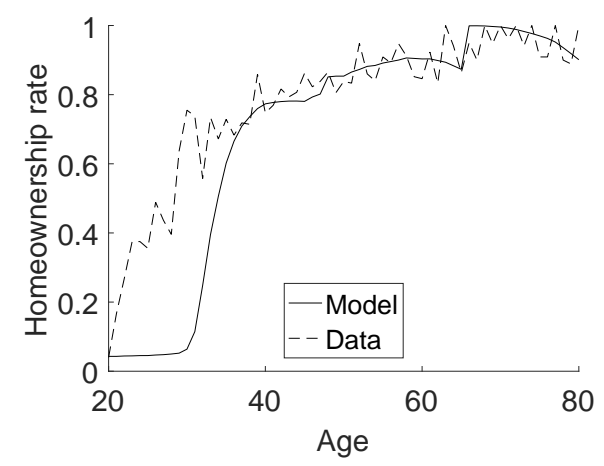

This figure depicts the evolution of homeownership rates over the life cycle. The solid lines show results generated with our model (Model); the dashed lines show the PSID data counterpart for high school graduates (Data).

\subsection{Predictions of the Model}

We need to ensure that simulated model predictions match key data patterns. We therefore compare simulated model predictions with the patterns of homeownership and household net worth constructed from the PSID data and its Wealth Supplements. The data sample used in examining the model fit covers the years 1999 and 2001, that is, the time period the divorce rates date from. ${ }^{24} \mathrm{We}$ outline the details of the data-selection process in Appendix C.

\subsubsection{Evolution of Homeownership Rates over the Life Cycle}

We begin the investigation of the predictions of our model by comparing the model-implied evolution of homeownership rates and net worth per adult with the data in Figures 4 and 5.

Figure 4 presents the evolution of homeownership rates over the life cycle. The solid lines show results generated by our model (Model); the dashed lines show the PSID data counterpart for high school graduates (Data). Figure 4 shows our model matches closely the homeownership rate over the life cycle. Our model's predictions are particularly sharp from age 35 . The following two factors-among others-may drive the discrepancy between our model's predic-

\footnotetext{
${ }^{24}$ We use two PSID waves to increase the data sample.
} 


\section{Figure 5}

\section{Evolution of homeownership and net worth for married and divorced}
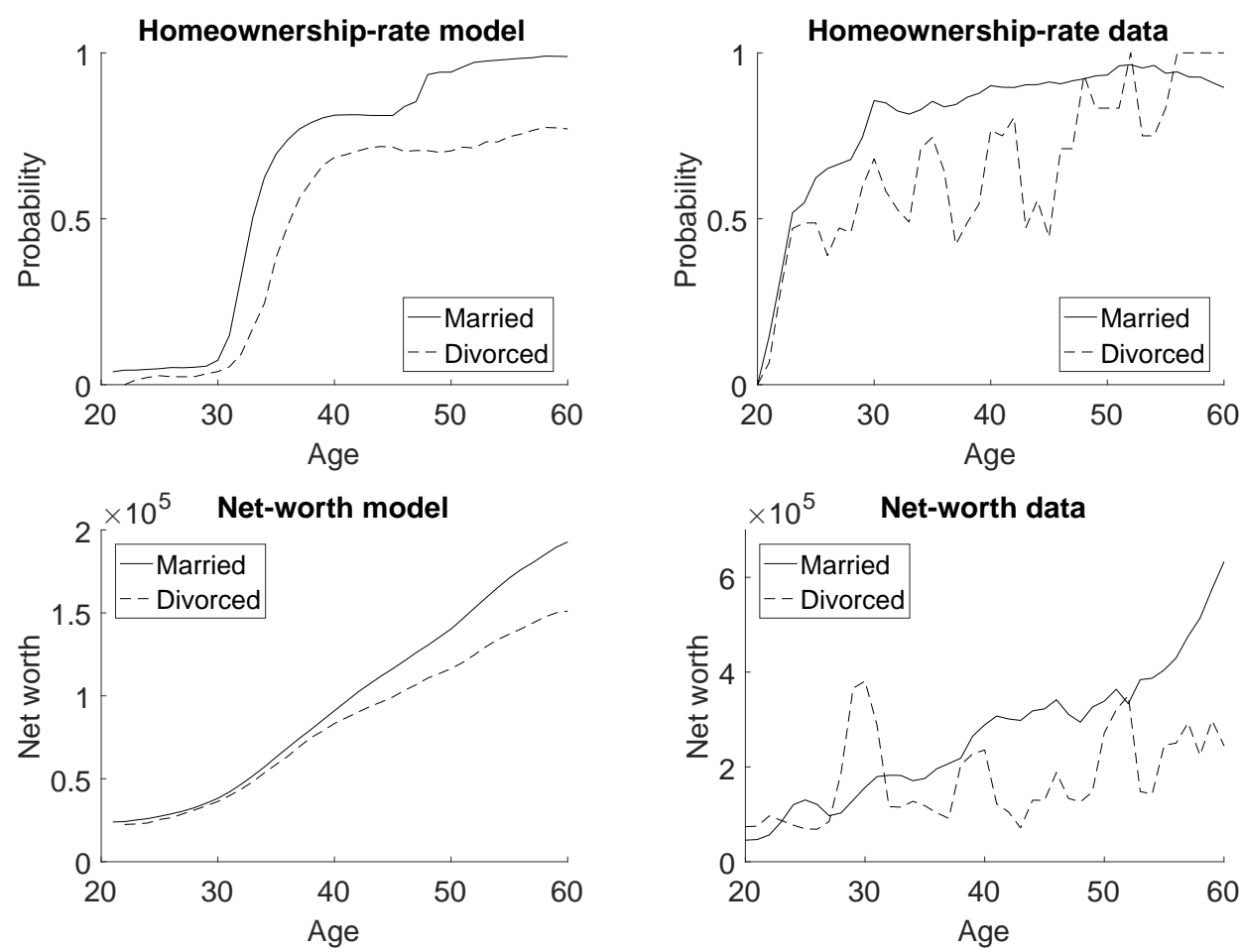

This figure depicts the evolution of the homeownership rate (upper panels) and the average net worth (including housing wealth) per adult living in the household (lower panel) over the life cycle for married (solid lines) and divorced individuals who are not remarried (dashed lines). The left panels depict results from 10,000 simulated paths of our model; the right panels depict results from the PSID data for high school graduates (averaged over a 3 -year age window). Levels of net worth in the PSID data are reported in 2008 USD.

tions and the data. In our model, individuals do not yet have children and are not yet married at the age of 20. They are therefore less likely to own a home. Next, we consider individuals with the same preferences, whereas in reality, individuals' preferences may exhibit heterogeneity. For individuals with the set of preferences studied in our work, living in a rented home is typically optimal at younger ages. Vestman (2018) shows that allowing for heterogeneity in preferences can generate a higher degree of dispersion in homeownership.

Figure 5 compares the evolution of homeownership rates and household net worth per adult for married and divorced individuals with their PSID data counterparts for high school graduates. Values for the data are shown as three-period moving averages over age. Similar to 
the patterns observed in the data, our model predicts divorced individuals are less likely to be homeowners and tend to be endowed with lower levels of net worth per adult than married individuals.

\subsubsection{Reduced-Form Determinants of Homeownership}

In this section, we compare our model predictions with the empirical evidence on how ever having gone through a divorce affects the homeownership status and how having recently gone through a divorce affects the propensity to move to an owner-occupied or rented home. For the empirical evidence on how having gone through a divorce affects homeownership status, we use the data from SIPP 2001 coupled with its Topical Module 2, because these data allow us to observe the entire histories of a person's lifetime marital transitions.

Table 3 shows that the negative relationship between divorce and homeownership indicated by Figure 5, survives in the individual-level regression of homeownership on the ever-divorced dummy, controlling for age, income-to-net worth ratio, and never having been married (the exclusion category is married and never divorced). The coefficient on the ever-divorced dummy is statistically significant and negative, suggesting that having gone through a divorce has a negative long-run effect on the probability of being homeowner.

We further explore how the model matches the transitional dynamics in homeownership and renting observed in the data. To illustrate the impact of marriage and divorce on the likelihood of becoming a homeowner or abandoning homeownership, we estimate a linear probability model of the decision to become a homeowner and abandon homeownership using simulated data from the model and the PSID data, and compare the results in Table 4. The observations in the simulated data are conditional on the individual's survival to avoid oversampling old individuals. ${ }^{25}$ The estimation results suggest our model predictions are commensurate with the empirical evidence that newly married individuals are more likely to acquire homeownership and newly divorced individuals are more likely to abandon it. ${ }^{26}$ Also, our model predictions

\footnotetext{
${ }^{25}$ In our model, we simulate 10,000 paths over 75 years, giving us 75,000 simulated observations. Conditioning on the individual's survival, we obtain 603,118 simulated observations.

${ }^{26}$ Using the model, we performed impulse-response analyses in which we shocked the individual's marital
} 
Table 3

Relation between homeownership and divorce

\begin{tabular}{lccc}
\hline & Data & Homeownership & Model \\
Ever divorced & -0.083 & -0.020 \\
Never married & $(0.006)$ & $(0.001)$ \\
& -0.203 & -0.026 \\
Age & $(0.008)$ & $(0.001)$ \\
& 0.008 & 0.011 \\
Age squared & $(0.0008)$ & $(0.0002)$ \\
Income-to-net-worth ratio & -0.00010 & -0.00008 \\
& $(0.00001)$ & $(0.00001)$ \\
Constant & -0.684 & -1.225 \\
& $(0.011)$ & $(0.002)$ \\
Number of observations & 0.900 & 0.882 \\
& $(0.021)$ & $(0.005)$ \\
\hline
\end{tabular}

This table reports results of the estimation of a linear regression of homeownership on an indicator for whether an individual has experienced a divorce, controlling for age, the income-to-net worth ratio, and never having been married. The exclusion category is married and never divorced. The regression reported in the column Data is estimated for females with the data from the SIPP 2001 and its Topical Module 2. The regression reported in the right column (Model) contains model-implied predictions conditional on the individual's survival. Standard errors are reported in parentheses.

match the empirical finding that households with young children are more likely to become homeowners.

Households with higher income-to-net-worth ratios are less likely to transition into homeownership and more likely to become renters. A high income-to-net-worth ratio indicates a household's savings are small relative to its income. Such a household is able to increase its future net worth at a faster rate. It may therefore prefer moving to a larger home in the future. To avoid the high transaction costs involved with trading owner-occupied homes, the household status. Consistent with the findings reported in Table 4, the results confirm that a marriage leads to an increase in homeownership and a divorce to a decrease in it. Similarly, an impulse-response analysis in which we shock the fertility predicts that a birth leads to an increase in the demand for homeownership. 
Table 4

\section{Housing decisions of movers}

\begin{tabular}{|c|c|c|c|c|}
\hline & \multicolumn{2}{|c|}{ Panel A: Become owner } & \multicolumn{2}{|c|}{ Panel B: Become renter } \\
\hline & Data & $\overline{\text { Model }}$ & Data & Model \\
\hline \multirow[t]{2}{*}{ Just married } & 0.153 & 0.003 & 0.080 & 0.022 \\
\hline & $(0.019)$ & $(0.001)$ & $(0.018)$ & $(0.002)$ \\
\hline \multirow[t]{2}{*}{ Just divorced } & -0.015 & -0.049 & 0.246 & 0.552 \\
\hline & $(0.022)$ & $(0.002)$ & $(0.022)$ & $(0.003)$ \\
\hline \multirow[t]{2}{*}{ Children age 0-4 } & 0.033 & 0.010 & -0.075 & 0.033 \\
\hline & $(0.014)$ & $(0.001)$ & $(0.013)$ & $(0.001)$ \\
\hline \multirow[t]{2}{*}{ Children age 5-10 } & 0.009 & 0.041 & -0.005 & -0.028 \\
\hline & $(0.012)$ & $(0.001)$ & $(0.012)$ & $(0.001)$ \\
\hline \multirow[t]{2}{*}{ Children age 11-17 } & -0.041 & 0.003 & -0.038 & -0.252 \\
\hline & $(0.012)$ & $(0.001)$ & $(0.011)$ & $(0.001)$ \\
\hline \multirow[t]{2}{*}{ Age $20-29$} & 0.111 & -0.004 & 0.181 & 0.171 \\
\hline & $(0.022)$ & $(0.001)$ & $(0.021)$ & $(0.002)$ \\
\hline \multirow[t]{2}{*}{ Age $30-39$} & 0.131 & 0.063 & -0.030 & 0.181 \\
\hline & $(0.020)$ & $(0.001)$ & $(0.019)$ & $(0.001)$ \\
\hline \multirow[t]{2}{*}{ Age $40-49$} & 0.077 & 0.022 & -0.058 & 0.128 \\
\hline & $(0.018)$ & $(0.001)$ & $(0.018)$ & $(0.001)$ \\
\hline \multirow[t]{2}{*}{ Age 50-59 } & 0.058 & 0.016 & -0.051 & 0.066 \\
\hline & $(0.018)$ & $(0.001)$ & $(0.018)$ & $(0.001)$ \\
\hline \multirow[t]{2}{*}{ Age $60-69$} & 0.016 & 0.013 & -0.028 & 0.074 \\
\hline & $(0.022)$ & $(0.001)$ & $(0.021)$ & $(0.001)$ \\
\hline \multirow[t]{2}{*}{ Income-to-net-worth ratio } & -0.081 & -0.008 & 0.354 & 1.206 \\
\hline & $(0.018)$ & $(0.001)$ & $(0.017)$ & $(0.002)$ \\
\hline \multirow[t]{2}{*}{ Constant } & 0.047 & 0.003 & -0.001 & -0.234 \\
\hline & $(0.015)$ & $(0.001)$ & $(0.015)$ & $(0.001)$ \\
\hline Number of observations & 4,755 & 603,118 & 4,755 & 603,118 \\
\hline
\end{tabular}

This table reports results of the estimation of a linear probability model documenting the impact of marriage and divorce on the decision to acquire homeownership (Panel A: Become owner) and abandon it (Panel B: Become renter). The "Children age" variables are dummy variables indicating whether children in the corresponding age group live in the household. We refer to individuals who got married or divorced between periods $t-1$ and $t$ as "just married" and "just divorced," respectively. The income-to-net-worth ratio in the PSID data is the latest available observations prior to the household move. Standard errors are reported in parentheses.

may prefer to remain a renter until it has increased savings.

The magnitude of the coefficients for being newly divorced tend to be higher in our model. In reality, resource reallocation during transition though divorce is likely being smoothed. 
Households in the data may sell their homes earlier than they formally get divorced. Also, they may sell their homes later, for example, because of long-lasting disputes over household finances, or a slow housing market. Our stylized life-cycle model abstracts away from such reasons. Nevertheless, from Figure 5, our model is able to match the long-term consequences of marriage and divorce, which our work is mainly concerned with, quite well.

\subsubsection{Changes in Divorce Rates and Homeownership}

In this section, we ask how changes in divorce rates affect homeownership rates. ${ }^{27}$ For that purpose, we pick a second date in history with different divorce rates and compare the modelpredicted impact on homeownership rates with the empirical evidence. Such an analysis is challenged by the need for detailed divorce rates, in particular, divorce rates by age, education, gender, and whether an individual has children - observed over two time periods with high and low divorce rates. For our base parameter setting, we constructed divorce rates using the retrospective information on marital events available in the SIPP 2001 and its Topical Module 2. Unfortunately, prior to this period, no data with marital transitions containing demographic characteristics on the same level of detail and, at the same time, being reliable and representative, are available. ${ }^{28}$ Going forward, since 2008, the American Community Survey (ACS) collects retrospective information on marriage and divorce that can be used to calculate divorce rates, conditional on age, education, gender, and the presence of children. In addition, the quality of information from ACS with about 3 million addresses per year is considered superior to other available sources of data on marital transitions (Ratcliffe et al., 2008). We use the 2010 ACS to construct the 2010 divorce rates in the same manner as outlined in section 3.6 for the 2001 base-case divorce rates.

Figure 6 depicts divorce rates per thousand married females in 2001 and 2010. Focusing on females with a high school education, Figure 6 confirms the empirical evidence on the general

\footnotetext{
${ }^{27}$ A related effect of changes in transitions to marriage on housing decisions is investigated in Chang (2018).

${ }^{28}$ Prior to 1996, the major source of the detailed vital statistics is the National Center for Health Statistics. However, the relevant information for divorce rates, including the children involved in divorce, is collected only for the group of states in the divorce-registration area, and divorces, accounted for in that sample, are less than half of all divorces (Clarke, 1995).
} 


\section{Figure 6}

\section{Comparison of divorce rates 2001 versus 2010}

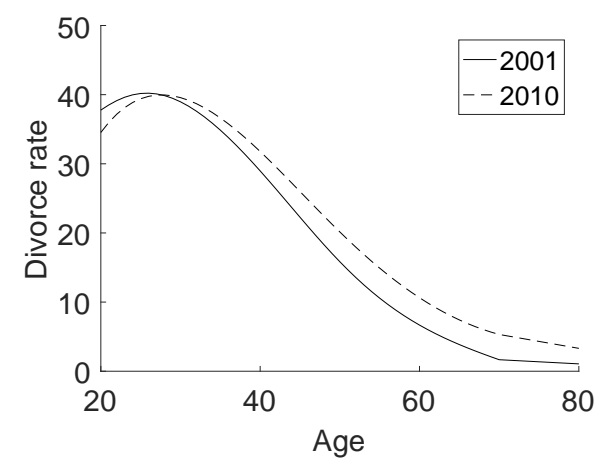

This figure depicts the divorce rates per thousand married female individuals with a high school degree, constructed over age as outlined in section 3.6. Values for 2001 are based on the SIPP 2001 and its Topical Module 2; values for 2010 are based on the American Community Survey. The solid line depicts divorce rates for 2001, and the dashed one for 2010.

rise in divorce rates for the majority of the US population demonstrated earlier in Figure 1. By 2010, divorce rates for high-school-educated females had generally increased, relative to the 2001 divorce rates. For instance, from Figure 6, about 22 45-year-old females out of a thousand experienced a divorce in 2001. In 2010, this number increased to 26 - an increase of more than 16 percentage points.

Using the model, we ask how the increase in divorce rates from the level of 2001 to the level of 2010 affected the demand for homeownership, and compare the model predictions with the empirical evidence in the PSID data. The left panel of Figure 7 compares modelpredicted homeownership rates over the life cycle using 2001 divorce rates (solid line) and 2010 divorce rates (dashed lines). Except for the divorce rates, all other parameters are chosen as in our base-case parameter setting. Hence, the left panel of Figure 7 isolates the effect of the change in divorce rates on homeownership rates. The right panel depicts the evolution of homeownership rates for female individuals with a high school degree in the PSID data. The solid line is based on the 1999 and 2001 data (PSID 2000), the dashed line on the 2009 and 2011 data (PSID 2010). 


\section{Figure 7}

\section{Comparison of homeownership rates with 2001 and 2010 divorce rates}
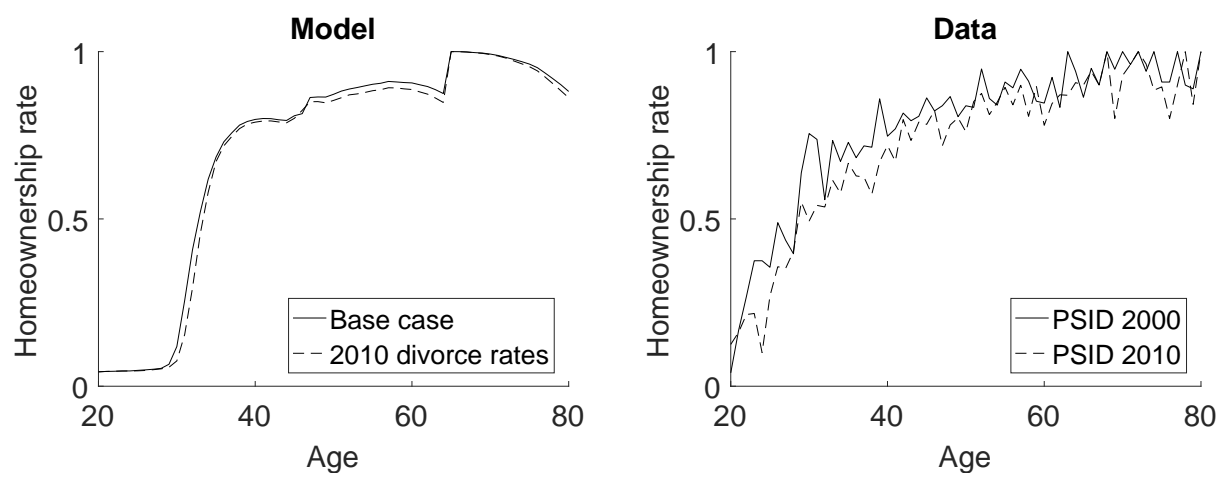

This figure depicts the evolution of homeownership rates over the life cycle in our model (left panel) with the empirical evidence in the PSID data (right panel) for individuals with a high school degree. The solid line in the left panel shows model-predicted homeownership rates conditional on the 2001 divorce rates; the dashed line shows model-predicted homeownership rates conditional on the 2010 divorce rates. The solid line in the right panel is based on the PSID data for the years 1999 and 2001 (PSID 2000); the dashed is based one on the PSID data for the years 2009 and 2011 (PSID 2010).

From the left panel of Figure 7, our model predicts homeownership rates fall when divorce rates increase. This result matches the empirically observed pattern in the right panel, in which homeownership rates in 2010 are lower than their 2000 counterpart. The decrease in homeownership rates is somewhat larger in the data than what our model predicts, suggesting that in addition to the increase in divorce rates from 2001 to 2010, other important economic factors have changed as well. For instance, in 2010, the demand for homeownership may have been affected by the aftermath of the 2007-2008 financial crisis.

\subsection{Effects of Divorce}

In this section, we investigate the long-term effect of the event of a divorce on homeownership rates and household net worth for an individual at the age of 30 , the median age at the first 


\section{Figure 8}

\section{Impulse-response analysis: Divorce at age 30}
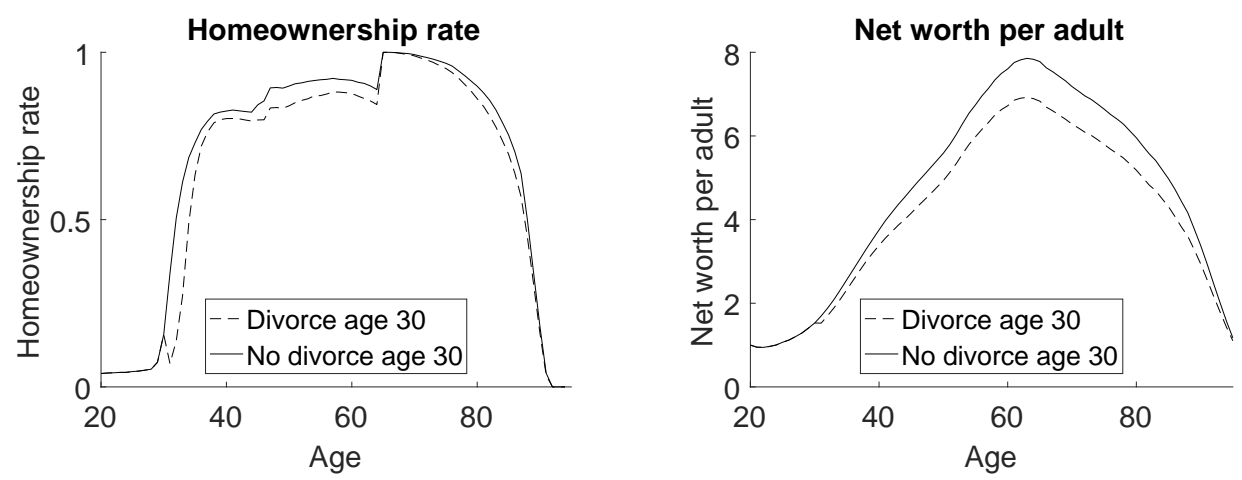

This figure depicts the impact of getting divorced at age 30 on homeownership rates (left panel) and household net worth per adult (right panel) for a female individual. All results reported are averages from the simulated paths, where the individual is married when turning 30. The dashed lines report results when the individual gets divorced at age 30; the solid lines report results when the individual does not get divorced at that age, but possibly later.

divorce for females in 2009 according to the US Census Bureau. ${ }^{29}$ We focus on the subsample of the 10,000 simulated paths, in which an individual is married when turning 30, and compare the evolution of homeownership rates and household net worth per adult when the individual gets divorced at age 30 (dashed lines) with results when she does not get divorced at that age, but possibly later (solid lines). Figure 8 shows that having gone through a divorce leads to long-lasting negative effects for the homeownership rate and household net worth per adult.

Although household wealth at divorce is split equally, divorce instantly affects household net worth per adult in the form of legal costs paid at the time of the divorce. Divorce also prevents individuals from benefiting from economies of scale. As a result, household net worth per adult is reduced and the reduction is persistent. The permanent negative effect on household net worth prevails even though divorced individuals may end up remarrying, and individuals not getting divorced at the age of 30 may get divorced at a later point in time.

In our model, the drop in homeownership is mainly driven through three channels. First, di-

\footnotetext{
${ }^{29} \mathrm{We}$ also explore the impact of divorce at other ages. Given that divorces at other ages do not qualitatively affect our results, we do not report results for these cases here. They are, however, available from the authors upon request.
} 
vorce instantly implies a sharp drop in household net worth due to the splitting of assets and the cost of divorce. Second, the newly divorced individual loses the economies of scale, implying she may face difficulties in financing the downpayment for a home that gives her utility similar to what she used to get before the divorce. Third, the new single's income is subject to a higher volatility than the former couple's. The correlation of income shocks and house-price changes renders housing investments riskier and hence less attractive (Cocco, 2005). These channels also explain why homeownership rates in the model drop with an increasing divorce rate. The results in this and the previous sections are consistent with the empirical analysis in section 2 and the findings in Tables 3 and 4, supporting the assertion that divorces increase the likelihood of abandoning homeownership.

\subsection{The Home Savings Motive and the Precautionary-Savings Motive}

In this section, we investigate how the opportunity to invest in owner-occupied homes affects household savings. We compare the net worth of individuals who can invest in owner-occupied homes with that of individuals in an economy in which owner-occupied homes cannot be acquired. We demonstrate that (1) individuals who can invest in owner-occupied homes build up higher net worth, and (2) under divorce risk, the higher savings of homeowners weaken the precautionary-savings motive.

We examine two economies. In the first economy, individuals can acquire owner-occupied homes and derive utility from living in them ("Base case"). In the second economy, households cannot acquire homeownership, must remain renters, and derive utility from housing as renters ("Renter"). To illustrate how divorce risk affects household savings for the two economies, we present household net-worth accumulation under two scenarios that differ by whether divorce risk is prevalent. Under one scenario, individuals are subject to divorce risk. These individuals' divorce rates correspond to the empirically observed divorce rates, and we assume individuals are aware of the level of divorce risk. Under another scenario, individuals are not subject to divorce risk and they know marriage cannot be dissolved through divorce. This hypothetical economy of no divorce is similar to the one studied in Cubeddu and Rìos-Rull (2003). For both economies, under no risk of divorce, we present the evolution of average household net 


\section{Figure 9}

\section{Comparison of evolution of net worth and increase due to divorce risk}
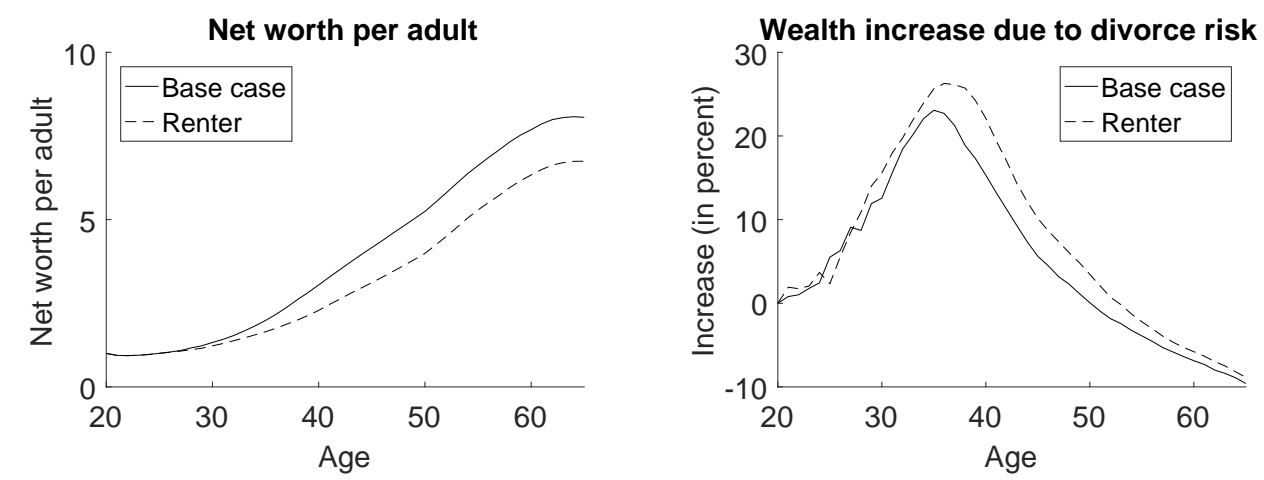

This figure depicts the evolution of average household net worth per adult over the life cycle (left panel) in the absence of divorce risk and the average increase in household net worth per adult obtained under the risk of divorce relative to a setting without divorce risk. The solid lines show results for our base-case setting in which households can purchase owner-occupied homes ("Base case") and the dashed lines show results for the case of forced renters ("Renter").

worth per adult over the life cycle. Next, we show the average increase in household net worth per adult obtained under the risk of divorce relative to a setting without divorce risk. Figure 9 presents the results.

The left panel of Figure 9 shows that the opportunity to invest in an owner-occupied home leads to higher savings. In addition to the consumption benefit from homeownership, an owneroccupied home is also attractive from an investment perspective. After taking into account maintenance costs and saved rent payments, the expected return from an investment in an owner-occupied home is 4.5 percent, which is higher than the return on the risk-free asset of 1.9 percent.

We proceed to investigate how households in the two economies respond to the risk of divorce. In the right panel of Figure 9, we compare the increase in household net worth induced by divorce risk in both economies. Households in both economies experience an increase in net worth for the large part of the working-life period, whereas for older households, the change in household net worth under divorce risk turns negative, reflecting the reduction in net worth due to asset-destruction costs of realized divorces as well as the loss of economies of scale. 
That is, divorce risk motivates young and middle-aged individuals to save for precautionary motives. In view of a lower share of the married population in the economy with divorce risk, which generally leads to a drop in net worth per adult, higher net worth per adult for young and middle-aged households under divorce risk is even more notable. Our findings on higher net worth under divorce risk is consistent with the precautionary-savings effect of divorce risk, found in Cubeddu and Rìos-Rull (2003), Fernández and Wong (2014), and Voena (2015). ${ }^{30}$ In these models, when choosing between consumption and non-housing investments, households save more under a higher risk of divorce. Our results in Figure 9 show the increase in household net worth in the two economies is relatively high, indicating divorce risk causes households to build up significant savings. The increase in savings peaks at about age 35, when divorce rates are still fairly high. As divorce rates decrease over the life cycle, so does the risk of divorce, which leads to the reduced strength of the precautionary-savings effect later in life.

Whereas we find that all households build up precautionary savings, the base-case households build up less precautionary savings than the "renters." In the "renters" economy, the relative wealth increase peaks at 26 percent at the age of 37 . In our base-case economy, the wealth increase due to divorce risk reaches 21 percent at that age. From the left panel of Figure 9 , in the absence of divorce risk, households that can invest in owner-occupied homes build up higher savings. Therefore, under divorce risk, not as much savings need to be set aside for precautionary reasons, leading to a reduced strength of the precautionary-savings effect. The higher levels of net worth built up in the base-case economy with homeownership partially substitute for precautionary savings.

\subsection{Divorce as a Risk Factor}

In this section, we further investigate how divorce risk affects household decisions. We compare homeownership and net worth of households in two economies that differ by whether divorce risk is prevalent. Our base-case economy is populated with individuals who are subject to divorce risk. Individuals in the other economy are not subject to divorce risk. Figure 10 illustrates our findings. The solid lines report results when individuals face divorce risk corre-

\footnotetext{
${ }^{30}$ González and Özcan (2013) find a similar effect.
} 


\section{Figure 10}

\section{Divorce risk and household decisions}
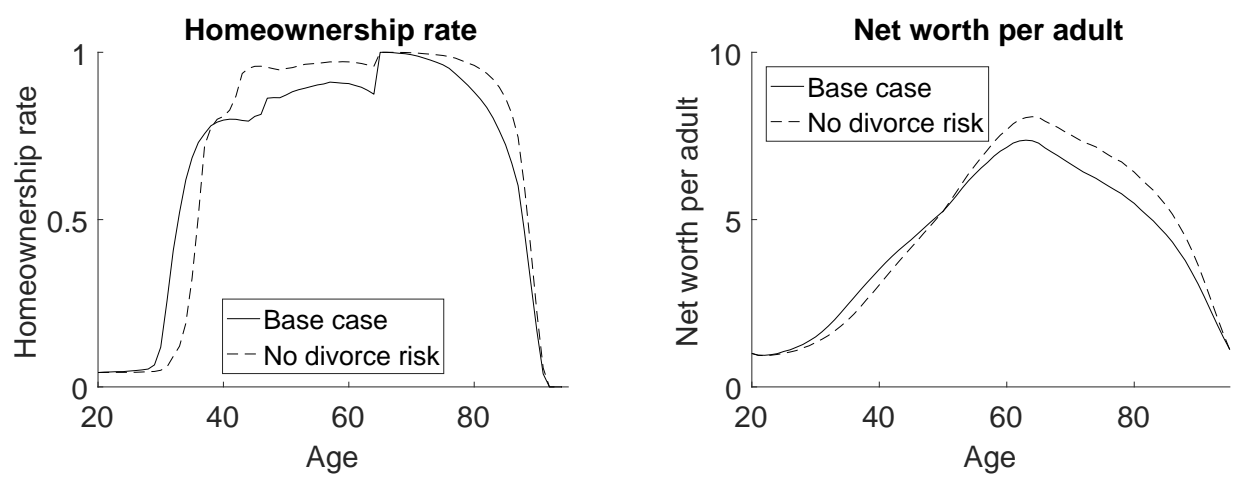

This figure depicts the impact of divorce risk on homeownership rates (left panel) and household net worth per adult (right panel). All results reported are averages from 10,000 simulated paths. The solid lines report results when individuals face divorce risk corresponding to the empirically observed probabilities (base case). Individuals know these divorce rates and behave accordingly. The dashed lines report when the divorce rate is zero (no divorce risk) and individuals are fully aware of not being subject to divorce risk.

sponding to the empirically observed divorce probabilities. The dashed lines report results in the absence of divorce risk.

Figure 10 shows net worth per adult is higher for younger households under the risk of divorce. In the presence of divorce risk, households save more to protect against the negative financial consequences of a possible divorce. As divorce risk induces a precautionary-savings motive, higher net-worth accumulation under divorce risk should enable households to save for downpayments faster, thereby speeding up the transition to homeownership and increasing the homeownership rate. However, buying a home is associated with a substantial transaction cost, which is forfeited when the home is sold in the event of a divorce. In the presence of a transaction cost, a household may delay the home purchase until it reaches higher levels of wealth and can afford to forfeit the transaction cost. The higher the divorce risk, the higher the option to delay the transition to homeownership, thereby reducing the homeownership rate. Thus, divorce risk can affect the homeownership rate through these counteracting channels.

From Figure 10, the homeownership rate of young households facing divorce risk is higher, indicating that for the young households, the higher level of precautionary savings facilitates 
making the downpayment for a reasonable-size home and easing their transition to homeownership. However, divorce risk decreases the homeownership rate for households of age 40 and older. Compared to the economy of no divorce, in the presence of divorce risk, the homeownership rate is reduced at age 40, even though the net worth per adult by the age of 40 is higher. That is, for the middle-aged and older households, the risk of an unintended sale upon divorce exceeds the effect from precautionary savings. In general, divorces result in the reduction of household wealth; therefore, the transaction cost to return to homeownership may be too expensive at lower levels of wealth, leading to a further reduction in homeownership rates for older households in the presence of divorce risk.

Our findings of the impact of divorce risk on homeownership resonate with the effect of another background risk factor - earnings risk, studied in Fisher and Gervais (2011). Higher earnings risk may lead to faster transition to homeownership because of higher savings due to precautionary reasons. Fisher and Gervais (2011) find the effect of the transaction-cost channel dominates the precautionary-savings channel, which can explain a part of the reduction in homeownership rates for young individuals. Divorce risk increases the odds of ending up in the state of higher income risk of a single household, strengthening the precautionary-savings motive for the young households, but leading to the reduction in the homeownership rate for middle-aged and older households despite their higher levels of accumulated wealth. Overall, our findings indicate that the possibility of divorce is an important risk factor, in addition to uncertainty in income and house prices - the risk factors found salient in the life-cycle literature with owner-occupied housing.

\section{Robustness}

In this section, we pursue two objectives. First, we demonstrate the robustness of our results by relaxing the assumption of perfect assortative mating in several dimensions. Second, we investigate how income insurance in marriage and the correlation between the growth rate of labor income and returns on owner-occupied homes affect homeownership, household net worth, and consumption.

Table 5 compares the evolution of homeownership rates (Ownership), household net worth, 
and consumption per adult over the life cycle under different settings. Results are reported for the base-case parameter setting (BC), a setting in which the partner has twice the individual's income (P2inc), twice the individual's net worth (P2nw), a college degree (Pcollege), and is two years older $(\mathrm{P}+2)$. We also report results for a setting in which correlation between the growth rate of labor income and the returns on owner-occupied homes is set to zero $\left(\rho_{L, H}=0\right)$, and a setting with no income insurance from marriage (Nii).

From Table 5, marriage to a partner with a higher income (column P2inc) leads to an increase in consumption and household net worth. Simultaneously, homeownership rates are lower than in the base-case setting. With higher incomes, individuals can afford higher consumption levels. The Cobb-Douglas preferences imply an optimal relationship between durable housing and non-durable consumption such that when consumption increases, households also increase their demand for living space. As a result, in marriage, they need to save for a larger downpayment, which takes longer. Marriage to a partner with a higher net worth (column P2nw) leads to higher household consumption and net worth. Unlike in the setting of marriage to a partner with a higher income, the higher partner's net worth at marriage is sufficient to cover the increased household needs in consumption and living space, which prompts households to acquire homeownership earlier in life. As a result, homeownership rates increase.

Marriage to a partner with a college degree (column Pcollege) leads to higher net worth and consumption, and homeownership rates that are higher for younger households. Higher homeownership at young age reflects higher labor-income growth for the young college-educated individuals. For older households, the higher volatility of labor income of college-educated households leads to slightly lower homeownership rates. Marriage to a partner who is two years older (column $\mathrm{P}+2$ ) leads to only marginal differences in homeownership rates, consumption, and household net worth. ${ }^{31}$

The correlation between the growth rate of the labor income and house prices is an important parameter in our model, because the degree of correlation indicates how useful a home is for diversifying labor-income risk. In the base-case scenario, we set the correlation between the

\footnotetext{
${ }^{31}$ Empirically, females marry a partner who is on average about two years older (Diaz-Gimenez and Giolito, 2013).
} 


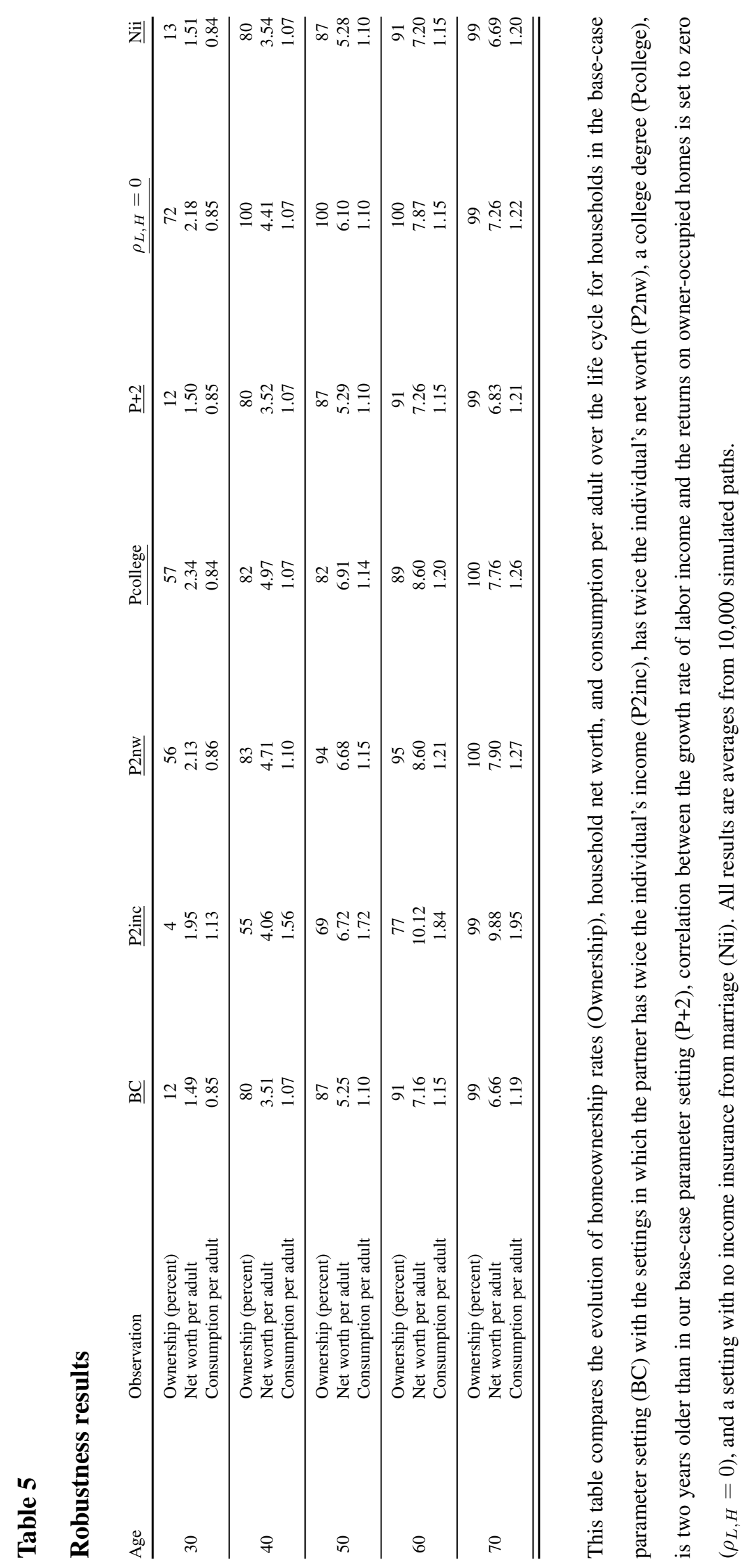


growth rate of the individual's labor-income process and house prices to the empirical estimate of Cocco (2005), $\rho_{L, H}=0.55$. His estimate is based on the correlation between aggregate income and aggregate house prices in the PSID. On the individual level, the correlation between the labor-income growth and house prices may be lower. Household income is only partly correlated with individual income due to an idiosyncratic component in an individual's labor-income stream. For the same reason, aggregate house-price movements should not be perfectly correlated with individual house-price movements. In Table 5, we investigate how setting the correlation between the growth rate of the individual's labor income and house prices to $\rho_{L, H}=0$ affects our findings. Even though a zero correlation may not be plausible, because the evolution of the local labor market and house prices should be correlated, it provides a lower bound on this parameter value.

In our model, retirement income is constant and therefore not subject to volatility. Because of the constant retirement income, at retirement age, the correlation between the growth rates of house prices and non-financial income is inconsequential, which leads to a remarkably high homeownership rate at that age, noticeable on Figure 4. Decreasing the correlation between labor-income growth and house prices to zero during working age should lead to a similar response in homeownership.

Our results in Table 5 show that setting the correlation between the growth rate of labor income and house prices to zero increases homeownership rates substantially. When correlation is lower, an investment in an owner-occupied home is better suited for diversifying laborincome risk. Hence, the improved financial characteristics of a home render it more attractive, which leads to an increase in demand for homeownership. For most of the life cycle, zero correlation makes an investment in an owner-occupied home so attractive that households with the set of preferences in our base-case parameter setting have a homeownership rate of 100 percent. $^{32}$

Income insurance from marriage comes from the volatility of a couple's labor-income

\footnotetext{
${ }^{32}$ Even for a correlation between the growth rates of labor income and house prices as low as $\rho_{L, H}=0$, our model is able to produce reasonable homeownership rates when calibrated with slightly different preference parameters. The results are available from the authors upon request.
} 
stream being lower than the volatility of an individual's labor-income stream. We account for the differences in labor-income volatility by following Love (2010) and estimating laborincome streams for single males, single females, and married couples separately. Although accounting for differences in the labor-income streams of single and married individuals is important, our approach faces challenges in separating two effects that may both lead to the documented reduction in the volatility of household income. On the one hand, married households often have two labor-income streams, thus leading to greater stability and a lower volatility of a couple's labor-income stream. On the other hand, married households tend to be older and therefore experience lower volatility in their labor income (Karahan and Ozkan, 2013). Also, a more stable labor-income stream may make an individual appear more attractive in the marriage market. To investigate how the income insurance from marriage affects our results, we conduct a robustness check by studying how our results change in the absence of income insurance from marriage. To do so, we increase the volatility of the couple's labor-income stream to the higher volatility of the single's labor-income stream.

The last column in Table 5 investigates to what extent our results are driven by income insurance from marriage. With the volatility of a single's labor-income stream exceeding the volatility of a married couple's labor-income stream, higher labor-income risk for single individuals might affect their propensity to acquire homeownership. Our results show that the increased volatility of a single's labor-income stream leads to very small increases in precautionary savings. Homeownership rates and consumption are largely unaffected. Overall, our results show that the income insurance from marriage only has a very small effect on our results.

\section{Conclusion}

This paper contributes to the literature on life-cycle wealth accumulation by investigating how divorce risk affects the demand for owner-occupied homes over the life cycle. In addition to being an investment, an owner-occupied home is a consumption good, trading of which is subject to a large transaction cost. To investigate housing decisions under divorce risk, we construct a life-cycle model of consumption, investment, and housing decisions, in which changes in family composition are drivers of homeownership and housing demand. 
Our model predicts the event of a divorce causes a decrease in household net worth and a long-lasting drop in the likelihood of being a homeowner. The opportunity to invest in owneroccupied homes generally increases household net worth. Simultaneously, this opportunity weakens the precautionary-savings motive, because higher savings of homeowners partly substitute for precautionary savings.

Divorce risk affects homeownership through two counteracting channels. Precautionary savings ease the transition to homeownership. However, households can be reluctant to buy homes to avoid incurring sizable transaction costs when the home is sold at divorce. Our model predicts divorce risk increases homeownership rates for the young households, for whom the precautionary-savings effect dominates. For the middle-aged and older households, we find the precautionary-savings channel is dominated by the reluctance to incur sizable transaction costs when the home can be sold at divorce. For these households, the risk of divorce leads to a reduction in homeownership rates. Consistent with the empirical evidence, our model predicts the recent increase in divorce rates leads to a decrease in homeownership rates for households beyond age 30 . 


\section{Appendix}

\section{A. Solution of Model}

We reduce the state space of the optimization problem by exploiting the homogeneity of the Cobb-Douglas function in $C$ and $Q$. Defining $v=V /\left(W_{t} / H_{t}^{\psi}\right)$, it holds that

$$
\begin{aligned}
& v\left(x_{t}, Y, t\right) \\
& =\sup _{\left\{c_{t}, q_{t}, I_{t}, \pi_{t}^{b}\right\}}\left[(1-\beta) \cdot U\left(c_{t}, q_{t}, I_{t}, M_{t}, N_{t}\right)^{1-\frac{1}{\phi}}\right. \\
& +\beta \cdot \mathbb{E}\left[M _ { t } \left\{f_{t} \tilde{f}_{t}\left(\frac{\frac{W_{t+1}}{W_{t}}}{\left(\frac{H_{t+1}}{H_{t}}\right)^{\psi}}\right)^{1-\gamma}\left(\frac{1}{2} v\left(x_{t+1}, Y, t+1\right)^{1-\gamma}+\frac{1}{2} v\left(x_{t+1}, \tilde{Y}, t+1\right)^{1-\gamma}\right)\right.\right. \\
& +f_{t}\left(1-\tilde{f}_{t}\right)\left(\frac{\frac{W_{t+1}}{W_{t}}}{\left(\frac{H_{t+1}}{H_{t}}\right)^{\psi}}\right)^{1-\gamma} v\left(x_{t+1}, Y, t+1\right)^{1-\gamma} \\
& \left.+\left(1-f_{t}\right) \tilde{f}_{t}\left(\frac{\frac{W_{t+1}}{W_{t}}}{\left(\frac{H_{t+1}}{H_{t}}\right)^{\psi}}\right)^{1-\gamma} v\left(x_{t+1}, \tilde{Y}, t+1\right)^{1-\gamma}\right\} \\
& \left.\left.(\mathrm{A} .10)+\left(1-M_{t}\right) f_{t}\left(\frac{\frac{W_{t+1}}{W_{t}}}{\left(\frac{H_{t+1}}{H_{t}}\right)^{\psi}}\right)^{1-\gamma} v\left(x_{t+1}, Y, t+1\right)^{1-\gamma}\right]^{\frac{1-\frac{1}{\phi}}{1-\gamma}}\right]^{\frac{1}{1-\frac{1}{\phi}}} \text {, }
\end{aligned}
$$

in which $c_{t}=C_{t} / W_{t}$ is the consumption-net-worth ratio, $q_{t}=Q_{t} / W_{t}$ is the household's normalized home size for which we have normalized $H_{t}$ to 1 , and

$$
x_{t}=\left[\frac{Q_{t-1} H_{t}}{W_{t}}, I_{t-1}, \frac{L_{t}}{W_{t}}, M_{t}, N_{t}^{e}, N_{t}^{l}, t\right]
$$

is the normalized vector of state variables. Hence, the policy functions $c_{t}, q_{t}, I_{t}$, and $\pi_{t}^{b}$, and the value function, $v$, depend on seven state variables: (1) the normalized size of the home, (2) homeownership status, (3) the income-to-net-worth ratio, (4) marital status, (5) the number of children born "early," (6) the number of children born "late," and (7) age.

We numerically compute the optimal policy function using backward induction in the discretized seven-dimensional state space. We discretize the continuous state variables: normal- 
ized value of the home, the income-to-net-worth ratio, and time. The expectation in equation (A.10) is computed using Gaussian quadrature. We employ parallel computation to expedite the optimization.

\section{B. Estimation of Income Process}

Income data are available in the PSID beyond the waves with the Wealth Supplement. For estimating the income process, we use panel data from the 1980-2011 waves of the PSID. We split our sample of high school graduates into three groups: single males, single females, and married couples. ${ }^{33}$ The estimation of income-process characteristics closely follows the procedure outlined in Cocco et al. (2005) and subsequently used by Love (2010). We construct income profiles for each group in two steps. First, we run a fixed-effects regression of the natural logarithm of income on a full set of age dummies and the number of children in different age brackets living in a household. Second, a polynomial of order three is fitted to the agedummy coefficients.

We compute the replacement ratio for each group in two steps as in Cocco et al. (2005). First, we run fixed-effects regressions of log income on age dummies for each demographic group separately. Second, based on these estimated dummies, we compute the average implied income for individuals aged 55-62 as a proxy for income prior to retirement. Likewise, we compute the average implied income for individuals aged 67-80 as a proxy for the first retirement income. The ratio between the latter and the former defines the replacement ratio. We estimate the variances of income shocks, using the procedure proposed by Carroll and Samwick (1997) and used in Cocco et al. (2005) and Love (2010), among others.

\section{Data Details}

In our comparison of model predictions with empirical evidence, we use micro-level data from the PSID along with its Wealth Supplements. For our base-case parameter setting, we com-

\footnotetext{
${ }^{33}$ With a slight abuse of wording, we refer to all partners cohabiting for more than one year, as being married. Similarly, we refer to separate partners as being divorced.
} 
pare model predictions with the years 1999 and 2001. For the case with the alternative 2010 divorce rates from the American Community Survey, we compare model-predictions with the PSID years 2009 and 2011. We exclude households in the Latino sample, the poverty sample, and the immigrant sample to keep our sample representative. We define household income as the sum of labor income and public transfers after taxes. ${ }^{34}$ We do not include financial income or private transfers, because we explicitly model these in our work. Income therefore only includes wages, bonus payments, overtime payments, tips, commissions and earnings, pensions, working compensation, unemployment compensation, value of food stamp benefits, TANF and other state program transfers, Supplemental Security Income payments, as well as other public welfare payments. Net worth is the sum of all assets (including the values of homes) minus all household debt. All monetary values reported are in 2008 dollars.

Similar to Love (2010), we restrict household income to be between $\$ 3,000$ and $\$ 3,000,000$, and household net worth to be positive. We further remove households with loan-to-net-worth ratios above 0.95 , reflecting that these households are more likely to default on their mortgages (Mayer et al., 2009). Likewise, we remove households with debt-to-net-worth ratios exceeding $20 .{ }^{35}$ We also remove observations with top-coded values, wild codes, and refused or ambiguous answers, such as households reporting they neither own nor rent the home in which they are living.

\section{References}

Bajari, P., P. Chan, D. Krueger and D. Miller, “A Dynamic Model of Housing Demand: Estimation and Policy Implications,” International Economic Review 54 (2013), 409442.

\footnotetext{
${ }^{34}$ Taxes are not available in the PSID data for the time period considered in our analysis. We therefore use the TAXSIM software developed by Feenberg and Coutts (1993) to compute taxes. The TAXSIM software is publicly accessible on the NBER's homepage: http://users.nber.org/ taxsim/.

${ }^{35}$ Such households' behavior is likely to be significantly affected by their debt, which goes beyond the scope of our work. This issue is, for instance, studied in more detail in Koijen et al. (2009), Cocco (2013), and Campbell and Cocco (2015).
} 
Baudin, T., D. DE LA Croix And P. GobBi, "Fertility and Childlessness in the United States," American Economic Review 105 (2015), 1852-1882.

Bertocchi, G., M. Brunetti And C. Torricelli, "Marriage and Other Risky Assets: A Portfolio Approach,” Journal of Banking and Finance 35 (2011), 2902-2915.

Bourassa, S. C., D. R. Haurin, J. L. Haurin, M. Hoesli And J. Sun, "House Price Changes and Idiosyncratic Risk: The Impact of Property Characteristics," Real Estate Economics 37 (2009), 259-278.

BredermeIER, C. AND F. JUESSEN, “Assortative Mating and Female Labor Supply,” Journal of Labor Economics 31 (2013), 603-631.

BROWn, S. L. AND I.-F. LIN, “The Gray Divorce Revolution: Rising Divorce Among MiddleAged and Older Adults, 1990-2010,” The Journals of Gerontology: Series B 67 (2012), 731741.

Bumpass, L. L., T. CAstro Martin And J. A. Sweet, “The Impact of Family Background and Early Marital Factors on Marital Disruption,” Journal of Family Issues 12 (1991), 22-42.

Campbell, J. Y. And J. F. Cocco, “A Model of Mortgage Default,” Journal of Finance 70 (2015), 1495-1554.

Carroll, C. D., "Buffer-Stock Saving and the Life Cycle/Permanent Income Hypothesis," Quarterly Journal of Economics 112 (1997), 1-55.

Carroll, C. D. And A. A. SAmwick, "The Nature of Precautionary Wealth," Journal of Monetary Economics 40 (1997), 41-71.

Case, K. E. And R. J. Shiller, "The Efficiency of the Market for Single-Family Homes," American Economic Review 79 (1989), 125-137.

ChAng, M., "House without a Ring: The Role of Changing Marital Transitions for Housing Decisions," mimeo, University of Pennsylvania, 2018. 
Chetty, R., N. Hendren And L. F. Katz, “The Effects of Exposure to Better Neighborhoods on Children: New Evidence form the Moving to Opportunity Expertiment," American Economic Review 106 (2016), 855-902.

Chetty, R. And A. SzeIDL, “Consumption Commitments and Risk Preferences,” Quarterly Journal of Eocnomics 122 (2007), 831-877.

CHOI, S., "Fertility Risk in the Life Cycle," International Economic Review 58 (2017), 237259.

Citro, C. F. And R. T. Michael, Measuring Poverty: A New Approach (Washington, DC: National Academy Press, 1995).

Clarke, S. C., “Advance Report of Final Divorce Statistics, 1989 and 1990," Monthly Vital Statistics Report 43 (1995), 1-32.

Cocco, J., "Portfolio Choice in the Presence of Housing," Review of Financial Studies 18 (2005), 535-567.

Cocco, J. F., "Evidence on the Benefits of Alternative Mortgage Products," Journal of Finance 68 (2013), 1663-1690.

Cocco, J. F., F. J. Gomes And P. J. Maenhout, “Consumption and Portfolio Choice over the Life Cycle," Review of Financial Studies 18 (2005), 491-533.

Cubeddu, L. AND J. V. Rìos-Rull, "Families as Shocks,” Journal of the European Economic Association 1 (2003), 671-682.

DAVIS, M. F., “The Marital Home: Equal or Equitable Distribution?,” University of Chicago Law Review 50 (1983), 1089-1115.

Diaz-Gimenez, J. And E. Giolito, “Accounting for the Time of First Marriage,” International Economic Review 54 (2013), 135-158.

Epstein, L. G. And S. E. Zin, "Substitution, Risk Aversion and Temporal Behavior of Consumption and Asset Returns: A Theoretical Framework," Econometrica 57 (1989), 937-969. 
FARnham, M., L. SChmidT And P. SEVAK, "House Prices and Marital Stability," American Economic Review: Papers and Proceedings 101 (2011), 615-619.

FEenberG, D. AND E. CoutTs, “An Introduction to the TAXSIM Model,” Journal of Policy Analysis and Management 12 (1993), 189-194.

Fernández, R. And J. C. Wong, "Divorce Risk, Wages and Working Wives: A Quantitative Life-Cycle Analysis of Female Labour Force Participation,” The Economic Journal 124 (2014), 319-358.

FIElds, J. AND L. M. CASPER, "America's Families and Living Arrangements," Current Population Reports, P20-537, Washington, DC: U.S. Census Bureau, 2001.

Fischer, M. And M. Stamos, “Optimal Life Cycle Portfolio Choice with Housing Market Cycles," Review of Financial Studies 26 (2013), 2311-2352.

Fisher, J. D. AND M. Gervais, "Why has Home Ownership Fallen Among the Young?," International Economic Review 52 (2011), 883-912.

GonzÁlez, L. And B. ÖzCAN, "The Risk of Divorce and Household Saving Behavior," Journal of Human Resources 48 (2013), 404-434.

Goodman, L., R. Pendall and J. Zhu, "Headship and Homeownership: What Does the Future Hold?,” Research report, Washington, DC: Urban Institute, 2015.

Gourinchas, P.-O. And J. A. PARKer, “Consumption over the Life Cycle,” Econometrica 70 (2002), 47-89.

GRAY, J. S., "Divorce-law changes, household bargaining, and married women's labor supply," American Economic Review 88 (1998), 628-642.

Green, R. AND M. White, "Measuring the Benefits of Homeowning: Effects on Children," Journal of Urban Economics 41 (1997), 441-461.

Greenwood, J., N. Guner, G. Kocharkov and C. Santos, "Marry Your Like: Assortative Mating and Income Inequality,” American Economic Review 104 (2014), 348-53. 
Greenwood, J., N. Guner, G. Kocharkov and C. Santos, "Technology and the Changing Family: A Unified Model of Marriage, Divorce, Educational Attainment and Married Female Labor-Force Participation,” American Economic Journal: Macroeconomics 8 (2016), 1-41.

Guner, N. And J. KnOwles, "Marital Instability and the Distribution of Wealth," Society for Economic Dynamics, 2007.

Haurin, D. R., T. L. Parcel And R. J. Haurin, "Does Homeownership Affect Child Outcomes?," Real Estate Economics 30 (2002), 635-667.

HuRD, M. D., “Mortality Risk and Bequest,” Econometrica 57 (1989), 779-813.

KARAHAN, F. AND S. OZKAN, "On the persistence of income shocks over the life cycle: Evidence, theory, and implications," Review of Economic Dynamics 16 (2013), 452-476.

Kennedy, S. And S. Ruggles, "Breaking Up Is Hard to Count: The Rise of Divorce in the United States, 1980-2010,” Demography 51 (2014), 587-598.

Kiyotaki, N., A. Michaelides And K. Nikolov, "Winners and Losers in Housing Markets," Journal of Money, Credit and Banking 43 (2011), 255-296.

Koijen, R. S., O. Van Hemert and S. Van Nieuwerburgh, "Mortgage Timing,” Journal of Financial Economics 93 (2009), 292-324.

Love, D. A., "The Effect of Marital Status and Children on Savings and Portfolio Choice," Review of Financial Studies 23 (2010), 385-432.

Marekwica, M., A. Schaefer And S. Sebastian, "Life Cycle Asset Allocation in the Presence of Housing and Tax-Deferred Investing," Journal of Economic Dynamics and Control 37 (2013), 1110-1125.

Mathews, T. J. And S. J. Ventura, "Birth and Fertility Rates by Educational Attainment: United States, 1994," Monthly Vital Statistics Report 45 (1997), 1-20. 
Mayer, C., K. Pence And S. Sherlund, “The Rise in Mortgage Defaults," Journal of Economic Perspectives 23 (2009), 27-50.

Mazzocco, M., C. Ruiz And S. Yamaguchi, "Labor Supply, Wealth Dynamics and Marriage Decisions,” Society for Economic Dynamics, 2014.

Ortalo-Magné, F. And S. Rady, "Boom in, Bust out: Young Households and the Housing Price Cycle,” European Economic Review 43 (1999), 755-766.

Ortalo-Magné, F. And S. Rady, "Housing Market Dynamics: On the Contribution of Income Shocks and Credit Constraints," Review of Economic Studies 73 (2006), 459-485.

Öst, C. E., "Housing and Children: Simultaneous Decisions? - A Cohort Study of Young Adults' Housing and Family Formation Decision," Journal of Population Economics 25 (2012), 349-366.

Ratcliffe, C. E., G. P. Acs, T. Dore And D. Z. Moskowitz, "Assessment of Survey Data for the Analysis of Marriage and Divorce at the National, State, and Local Levels," Research report, Washington, DC: Urban Institute, 2008.

Ruggles, S., K. Genadek, R. Goeken, J. Grover and M. SobeK, "Integrated Public Use Microdata Series: Version 7.0,” Minneapolis, MN: University of Minnesota (2017).

SANTOS, C. AND D. WEISS, "Risky Income, Risky Family: Marriage and Divorce in a Volatile Labor Market," University of Pennsylvania, 2012.

Santos, C. And D. WeIss, "Why Not Settle Down Already? A Quantitative Analysis of the Delay in Marriage," International Economic Review, 57 (2016), 425-452.

Scholz, J. K., A. Seshadri And S. Khitatrakun, "Are Americans Saving Optimally for Retirement?,' Journal of Political Economy 114 (2006), 607-643.

SCHWARTZ, C. R. AND R. D. MARE, “Trends in Educational Assortative Marriage from 1940 to 2003," Demography 42 (2005), 621-646. 
SinaI, T. AND N. S. Souleles, "Owner-Occupied Housing as a Hedge Against Rent Risk," Quarterly Journal of Economics 120 (2005), 763-378.

Stevenson, B., "The Impact of Divorce Laws on Marriage-Specific Capital," Journal of Labor Economics 25 (2007), 75-94.

Stevenson, B. And J. Wolfers, "Marriage and Divorce: Changes and their Driving Forces," Journal of Economic Perspectives 21 (2007), 27-52.

Stevenson, B. And J. Wolfers, Research Handbook on the Economics of Family Law, chapter Trends in Marital Stability (Cohen, Lloyd R. and Wright, Joshua D., 2011), 96-108.

Turly, R. N. And M. Desmond, “Contributions to College Costs by Married, Divorced, and Remarried Parents,” Journal of Family Issues 32 (2011), 767-790.

TURner, B. R., "Unlikely Partners: The Marital Home and the Concept of Separate Property," Journal of the American Academy of Matrimonial Lawyers 20 (2006), 69.

VAn Hemert, O., "Household Interest Rate Risk Management," Real Estate Economics 38 (2010), 467-505.

Vestman, R., "Limited Stock Market Participation Among Home Owners and Renters," Review of Financial Studies, forthcoming (2018).

Voena, A., "Yours, Mine, and Ours: Do Divorce Laws Affect the Intertemporal Behavior of Married Couples?,” American Economic Review 105 (2015), 2295-2332.

YAO, R. AND H. H. Zhang, "Optimal Consumption and Portfolio Choices with Risky Housing and Borrowing Constraints," Review of Financial Studies 18 (2005), 197-239. 